New Cretaceous Formations in the Western Wyoming Thrust Belt
GE OLOGICAL
S UR V E Y
BUILETIN
$1372-I$ 


\section{New Cretaceous Formations in the Western Wyoming Thrust Belt}

By WILLIAM W. RUBEY

\section{CONTRIBUTIONS TO STRATIGRAPHY}
G E O L O G I C A L
S UR VEY
B U LLET IN
$1372-I$

Westward equivalents of Bear River and Aspen Formations are divided into five new formations by two red-bed tongues of the Wayan Formation. The Hilliard Shale changes northward to sandstone of the upper part of the new Blind Bull Formation

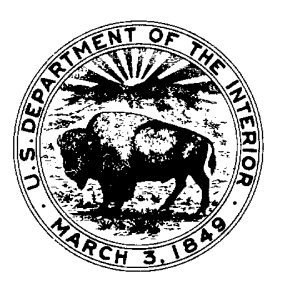




\section{UNITED STATES DEPARTMENT OF THE INTERIOR ROGERS C. B. MORTON, Secretary}

\section{GEOLOGICAL SURVEY}

V. E. McKelvey, Director

For sale by the Superintendent of Documents, U. S. Government Printing Office Washington, D. C. 20402 - Price 50 cents (paper cover) Stock Number 2401-02402 


\section{CONTENTS}

$\begin{array}{lr}\text { Abstract } & \text { Page } \\ \text { Introduction } & \text { I1 } \\ \text { Lower Cretaceous } & 1 \\ \text { Smiths Formation } & 5 \\ \text { Thomas Fork Formation } & 19 \\ \text { Cokeville Formation } & \text { Quealy Formation } \\ \text { Sage Junction Formation } & \\ \text { Upper Cretaceous } & \\ \text { Blind Bull Formation } & \\ \text { References cited } & \end{array}$

\section{ILLUSTRATIONS}

FIGURE 1. Map showing central part of thrust belt of western Wyoming, southeastern Idaho, and northeastern Utah

2. Northwest-southeast sections, showing lateral relations of Cretaceous rock units above the Gannett Group

3-6. Geologic maps showing type localities:

3. Smiths Formation

4. Thomas Fork Formation

5. Cokeville and Quealy Formations

6. Sage Junction Formation

7. Sections showing lateral relations of Upper Cretaceous formations in the

Kemmerer, Cokeville, and Afton quadrangles

8. Geologic map, showing location of type section of the Blind Bull Formation and of the upper and lower tongues of the Hilliard Shale 



\title{
CONTRIBUTIONS TO STRATIGRAPHY
}

\section{NEW CRETACEOUS FORMATIONS IN THE WESTERN WYOMING THRUST BELT}

\author{
By William W. Rubey
}

\begin{abstract}
Six new formations are named and defined for distinctive rock sequences mapped in several quadrangles in the central part of the western Wyoming thrust belt. Previously recognized rock-stratigraphic units in the region are inapplicable to the sequences.

A western sequence of Lower Cretaceous rocks is divided into five formations by two units of variegated mudstone regarded as southeastward-extending tongues of the Wayan Formation red beds. The basal formation, the Smiths Formation, directly above the Gannett Group and about 750 feet thick near the type section, consists of ferruginous black shale and tan quartzitic sandstone. The overlying Thomas Fork Formation, about 1,000 feet thick, consists of banded and variegated red, purple, brown, and green mudstone and some gray to tan sandstone. The middle formation, the Cokeville Formation, about 1,600 feet thick, consists of gray sandstone, siltstone, and claystone, $\tan$ limestone, and porcelanite, bentonite, and coal. The Quealy Formation, about 1,000 feet thick, consists of red and variegated pastel-tinted mudstone and pink, gray, and tan sandstone. The Sage Junction Formation, at the top of the Lower Cretaceous sequence, is more than 3,000 feet thick and consists mainly of gray and tan siltstone, sandstone, and quartzite but also contains porcelanite, limestone, conglomerate, and some coal. The Smiths, Thomas Fork, and lower part of the Cokeville Formations are approximately correlative with the Bear River Formation in the eastern part of the thrust belt, although parts of the Smiths may be older. The upper part of the Cokeville and Quealy Formations and most of the Sage Junction Formation are correlative with the Aspen Shale. The uppermost several hundred feet of the Sage Junction Formation may contain beds equivalent in age to parts of the Frontier Formation.

In the eastern part of the thrust belt, the marine Hilliard Shale, which separates the underlying Frontier Formation from the Adaville Formation, becomes increasingly sandy northward and northwestward until divisions of the Upper Cretaceous sequence can no longer be mapped. The Blind Bull Formation, more than 5,000 feet thick, is the name proposed for this Upper Cretaceous sequence; the formation is separated into the lower and upper parts by the mappable lower and upper tongues of the Hilliard Shale on the east, but not on the west. The Blind Bull consists of partly conglomeratic sandstone, siltstone, claystone, coal, and bentonite. It is directly underlain by the Aspen Shale and overlain, where mapped thus far, by thrust plates of older rock. The Shurtliff Sandstone Member of the Hilliard Shale near Kemmerer is regarded as a southward-extending tongue of the Blind Bull Formation.
\end{abstract}

\section{INTRODUCTION}

Geologic mapping in the central part of the thrust belt of western Wyoming revealed some new rock-stratigraphic units that differ from 
Cretaceous formations formerly described (Veatch, 1907; Schultz, 1914; Mansfield, 1927) and still commonly recognized within the region. These new formations are depicted on the geologic map of the Afton quadrangle

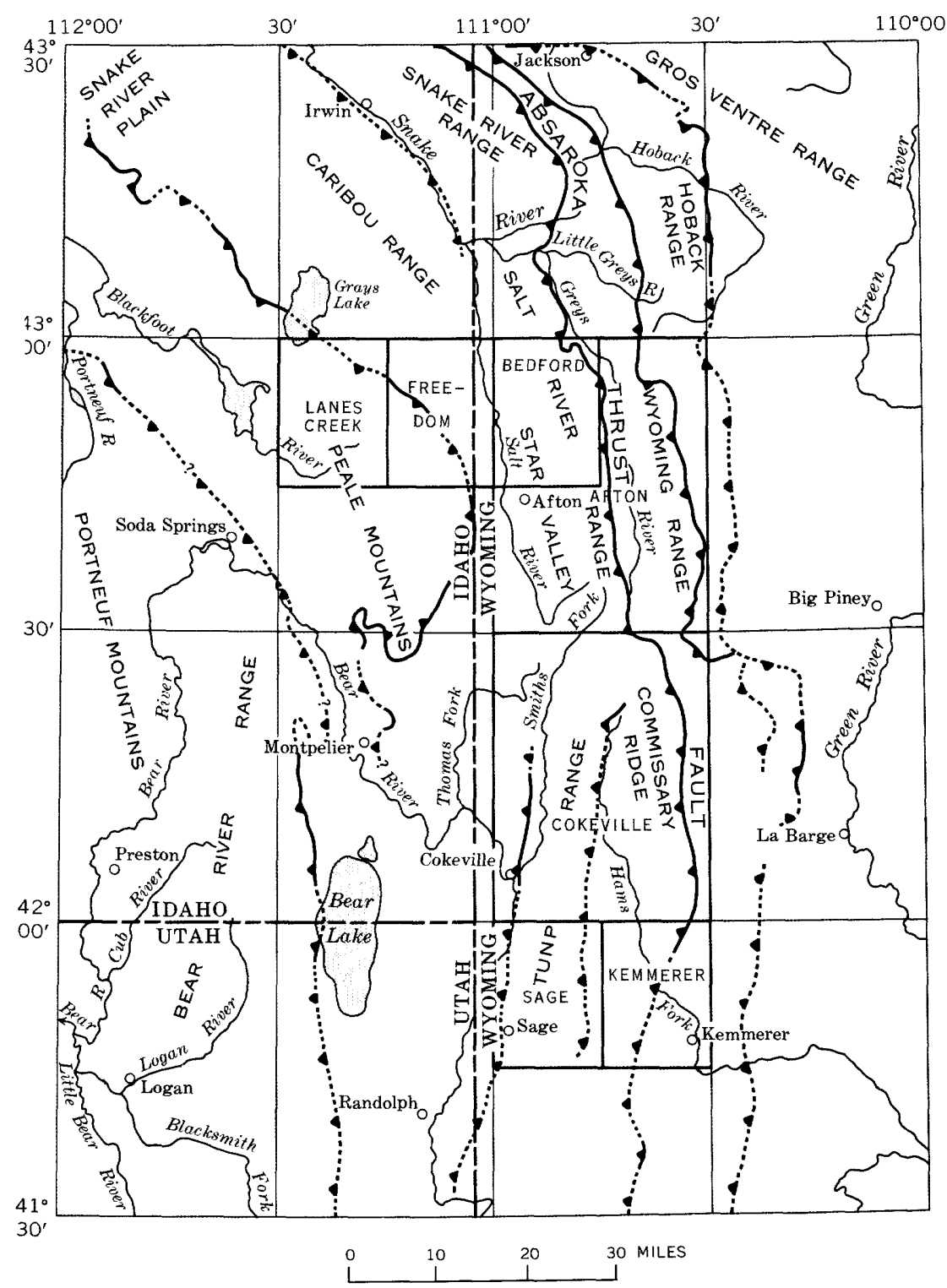

FiguRE 1. - Map showing central part of thrust belt of western Wyoming, southeastern Idaho, and northeastern Utah, and quadrangles mentioned in this report. Principal thrust faults indicated by sawteeth, which are on upper plate; dotted where concealed. 
(Rubey, 1973) and on geologic maps that are being prepared on the Cokeville quadrangle (W. W. Rubey, J. I. Tracey, Jr., and S. S. Oriel) and on the Sage and Kemmerer quadrangles (W. W. Rubey, S. S. Oriel, and J. I. Tracey, Jr.) (fig. 1).

The purpose of this contribution is to describe these new formations and the type sections upon which they are based so they might serve as a basis for future studies of the Cretaceous tectonostratigraphic history of the region. My understanding of these units was helped immeasurably by discussions with, and contributions by, the late John B. Reeside, Jr. We examined numerous sections of these rocks together, and many of the fossils found supporting the physical relations were identified by Reeside. In fact, the present report was to have been a joint paper by the two of us, and we were both working on it at the time of his unfortunate death in 1958. The companionship in the field, during the later years of this study, of Joshua I. Tracey, Jr., and Steven S. Oriel was both helpful and stimulating, and I especially thank Oriel for preparing a draft of this report that encouraged me to return to an earlier draft that I had set aside after John Reeside's death. I also thank Daniel A. Jobin and Donald E. Trimble, whose suggestions substantially improved the report.

\section{LOWER CRETACEOUS}

Sedimentary rock sequences above the Gannett Group in the western part of the region differ markedly in composition and thickness from those in the eastern part which have been assigned to the Bear River and Aspen Formations. These differences are so marked that the same rock-stratigraphic designations cannot logically be applied to both. The eastern sequence is exposed east of the trace of the Absaroka fault, whereas the western sequence is present in the several thrust plates west of and above the Absaroka fault. Although parts of the western sequence resemble lithologies assigned to the Bear River and Aspen Formations, accounting for previous use of these names west of the Absaroka fault, an entirely new division has proved more practical in mapping and is more expressive of the facies relations that merit formal recognition. Informal brief descriptions of the divisions have been published previously (as in Moritz, 1953, p. 69).

At no place are the eastern and western sequences exposed in lateral contact. Everywhere they are separated by areas from a few to several miles wide where these beds either have been eroded away or are buried under higher thrust plates. The inferred lateral relations of the formations in the two sequences are shown in figure 2.

The Gannett Group directly beneath the new units has been sufficiently well described in recent reports (Eyer, 1969; Furer, 1970) that repetition in this report is unnecessary.

The western sequence of Lower Cretaceous rocks above the Gannett Group is divided here into five new formations. These formations are named, in ascending order, the Smiths, Thomas Fork, Cokeville, Quealy, 

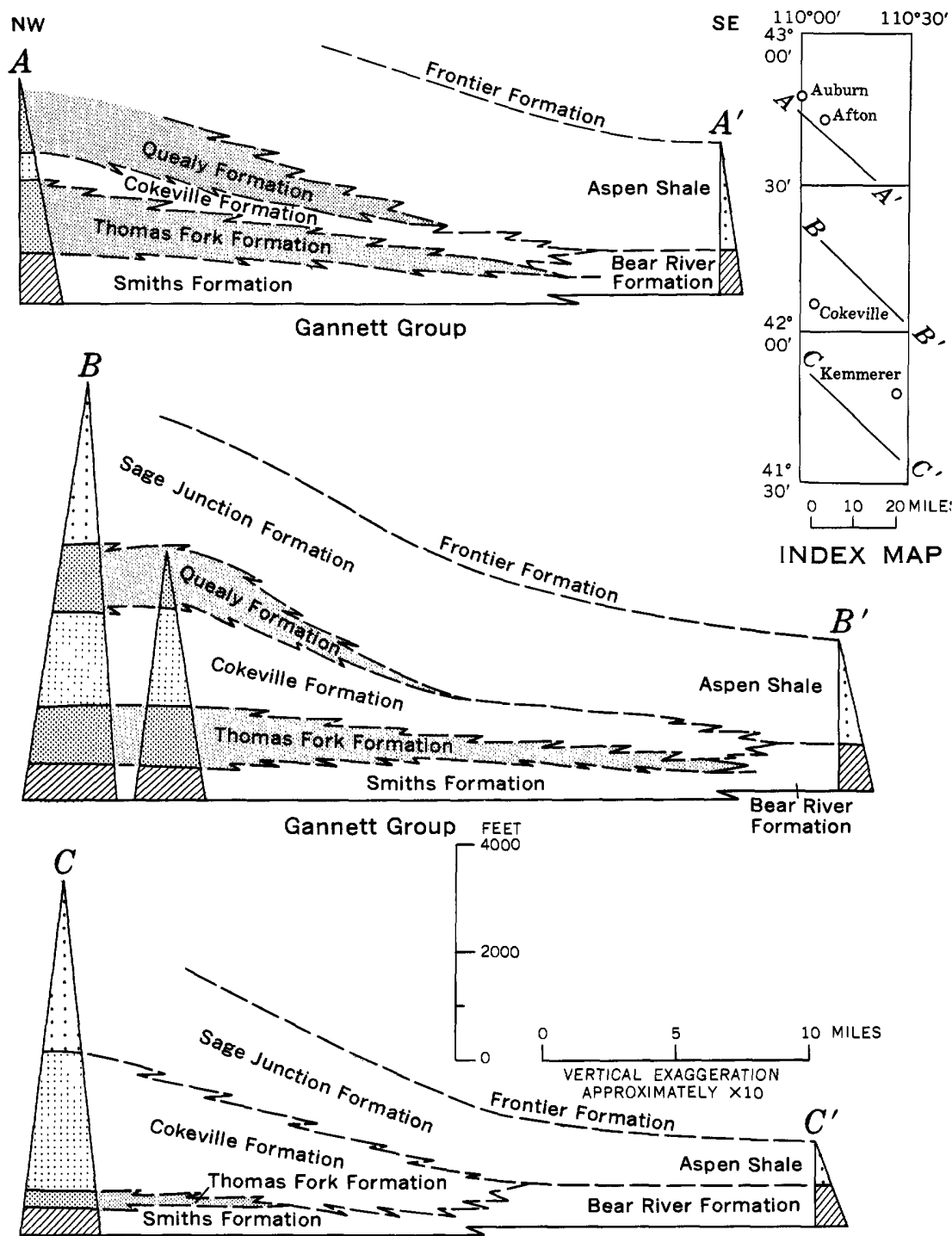

Gannett Group

FIGURE 2. - Northwest-southeast sections, showing the probable lateral interfingering relations of Cretaceous rock units above the Gannett Group at their westernmost exposures near the western border of Wyoming with the eastern facies of rocks formed at the same time over wide areas in western Wyoming. Dark patterns indicate location of measured sections.

and Sage Junction Formations for geographic features in the areas in which they have been mapped.

The bottom, middle, and top formations consist mainly of strata that resemble somewhat those assigned on the east to the Bear River and Aspen 
Formations. The intervening Thomas Fork and Quealy Formations, however, consist mainly of variegated mudstones and sandstones that have no recognized counterparts in the east. These variegated units may be regarded as south- and southeastward-extending tongues of the mainly red Wayan Formation described by Mansfield (1927, p. 105) for the Lanes Creek and Freedom quadrangles. The intervening Cokeville Formation pinches out northwestward toward the Freedom quadrangle, where a threefold division - the Smiths, Wayan, and Sage Junction Formations has been mapped by S. S. Oriel and L. B. Platt (unpub. data, Dec. 6, 1971). However, because Mansfield (1927, pl. 5) initially mapped many rocks as Wayan in the Freedom quadrangle that belong instead to the Gannett Group, his understanding and description of the Wayan (p. 105-108) were less than clear and accurate, according to my own observations and those of J. B. Reeside, Jr., which are confirmed by S. S. Oriel and L. B. Platt (written commun., Dec. 6, 1971). Redefinition of the Wayan Formation is clearly necessary but lies beyond the scope of this report.

The proposed Smiths Formation, which contains abundant black shale, and the proposed Cokeville Formation, which contains beds of highly fossiliferous and Pyrgulifera-bearing limestone, are not treated here as simply tongues of the Bear River Formation interfingering northwestward into time-equivalent red and variegated strata. Abundant beds of quartzitic sandstone and of the highly distinctive Kootenai-Cloverly fauna (which has not been found in typical Bear River) and the absence of the characteristic coquinas and fossils of the Bear River in the proposed Smiths Formation make it inadvisable to consider these beds as simply a northwestern tongue of the Bear River Formation; rather, they should be ranked as an independent formation. Similarly, the presence of numerous coaly beds and of fossils of post-Bear River age and the absence of characteristic black shale of the Bear River Formation make the Cokeville Formation compositionally distinctive from the Bear River.

In general, the Smiths, Thomas Fork, and lower part of the Cokeville Formations are approximately the same age as the Bear River Formation, although parts of the Smiths may be somewhat older. The upper part of the Cokeville, and Quealy, and much of the Sage Junction Formations are probably the same age as the Aspen Shale. The uppermost beds of the Sage Junction Formation may represent parts of the Frontier Formation.

\section{SMITHS FORMATION}

The Gannett Group is directly overlain, in the hills along Smiths Fork, by a unit here named the Smiths Formation. Its lower unnamed member consists mainly of ferruginous black shale, and the upper unnamed member, of tan very fine grained quartzitic sandstone, although these rock types are interbedded and are present throughout the formation. The formation is particularly well exposed farther north, close to the Smiths Fork Guard Station of the U.S. Forest Service, for which it is named, in the Cokeville 30-minute quadrangle. 
The noncalcareous black fissile shale and the tan fine-grained quartzitic sandstone beds of the Smiths Formation are readily distinguished from the gray limestone and calcareous red, purplish, and gray siltstone beds of the underlying Gannett Group and from the variegated mudstone and sandstone and nodular limestone of the overlying Thomas Fork Formation.

The upper member of the formation, the tan fine-grained quartzitic sandstone, is the same as that which was called the Tygee Sandstone by Mansfield and Roundy in their paper $(1916$, p. 83) in which the formations of the Gannett Group and the overlying Wayan Formation were first described. The upper, sandstone member of the Smiths Formation is exposed on the ridge along the Idaho-Wyoming boundary (Mansfield, 1927, pl. 7) near the type locality of the Draney Limestone (sec. 10, T. 8 S., R. 46 E., Idaho), with which it is locally in fault contact. As a result of this juxtaposition, the sandstone was inadvertently included by Mansfield and Roundy in their Gannett Group.

A respectable but not convincing case can be made for retaining the name Tygee Sandstone for what is here called the upper, sandstone member of the Smiths Formation and restricting the name Smiths to the lower, shale member. However, the two rock types, black fissile shale and tan quartzitic sandstone, are interbedded with one another, and both are present throughout the formation.

At some localities the dark shale is intercalated with thin beds of quartzitic sandstone like that in the thicker beds above, and where exposures are sufficiently good, the thick beds of sandstone in the upper part commonly alternate with thinner beds of dark shale and siltstone. At a few places the thin sandstones in the lower part thicken and the thicker beds of sandstone in the upper part grade laterally into shale and siltstone and so the main sandstone development is in the lower rather than the upper part of the unit. For these reasons and because the black shale is the most persistent and diagnostic lithology for this part of the section, it seems best and simplest for economy of stratigraphic nomenclature to propose, albeit reluctantly, that the name Tygee Sandstone be abandoned and that Smiths Formation be used to include both of the two dominant lithologic types.

The type section of the Smiths Formation (fig. 3) is designated as that measured across a ridge $1.1-1.4$ miles N. $68^{\circ} \mathrm{W}$. of the Smiths Fork Guard Station in the NW1/4NE $1 / 4$ sec. 27 of the unsurveyed T. 29 N., R. 118 W., where the formation is about 700 feet thick. The formation is thicker, about 755 feet thick, where it is poorly exposed along the north bank of Smiths Fork, directly east of the guard station. This somewhat more accessible exposure, along a road, is here designated as one of two nearby reference sections. The formation is thinner, 300-400 feet thick, in the Sage and Kemmerer quadrangles. Fossils collected from the formation and reported on by J. B. Reeside, Jr., establish its Early Cretaceous age. 


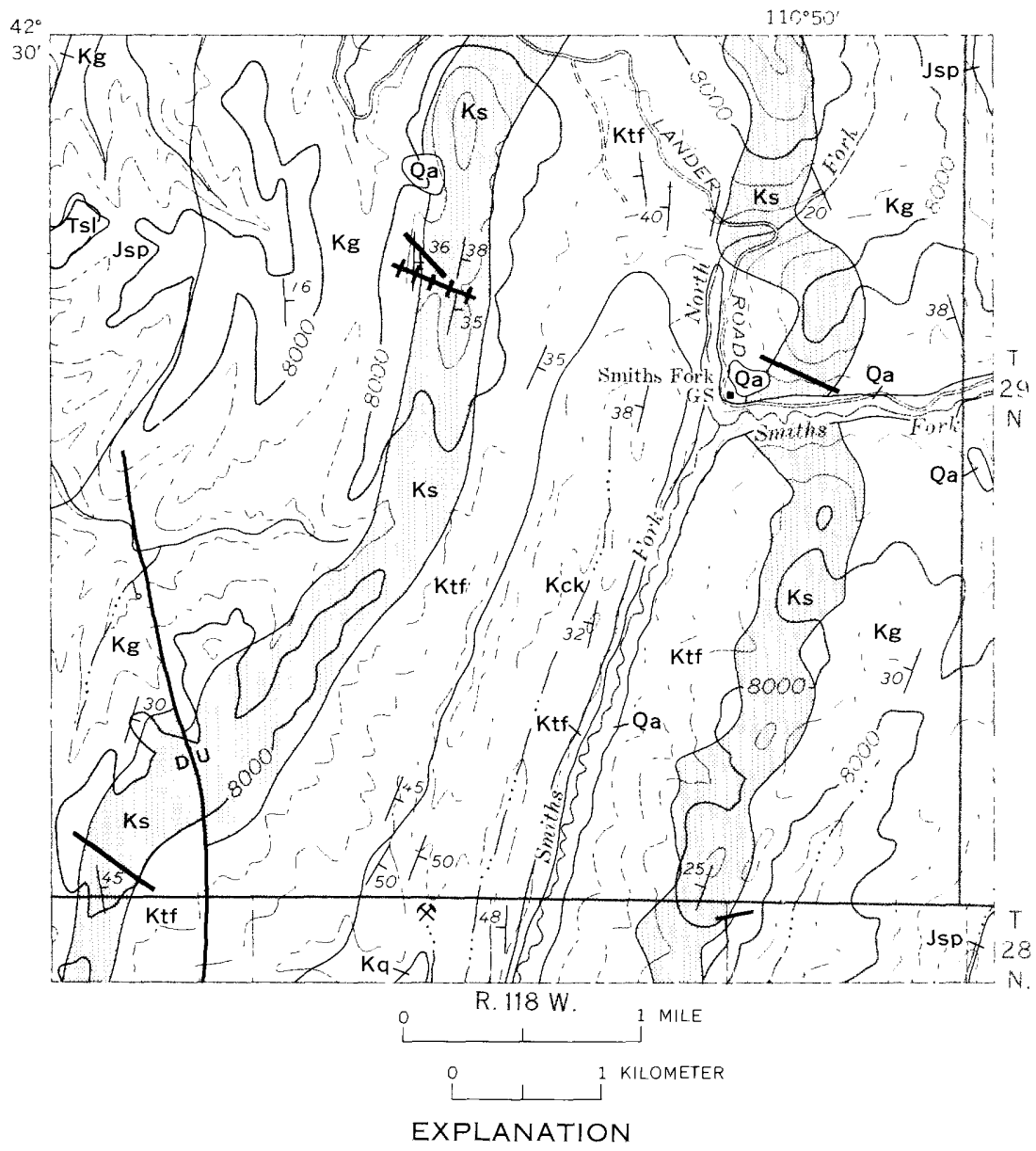

Qa Alluvium and colluvium - QUATERNARY

TsI Salt Lake Formation - TERTIARY

Kq Quealy Formation

Kck Cokeville Formation

Ktf Thomas Fork Formation

Ks Smiths Formation

Kg Gannett Group

Jsp Stump Sandstone and

Preuss Red Beds

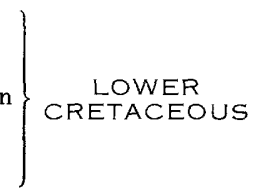

\} UPPER JURASSIC

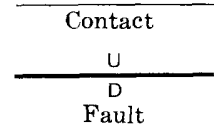

$\mathrm{U}$, upthrown side

$\mathrm{D}$, downthrown side

$$
\begin{aligned}
& \frac{1}{\text { Strike and }} \\
& \text { dip of beds } \\
& \text { Coal prospect }
\end{aligned}
$$

FIGURE 3. - Geologic map of the southeastern part of T. 29 N., R. 118 W., showing locations of type section (line with crossbars) and two reference sections (straight lines) of the Smiths Formation (stippled) in the Cokeville 30-minute quadrangle. Contour interval, 200 feet. 


\section{Type section of the Smiths Formation}

[1/4 miles west-northwest of Smiths Fork Guard Station, NW1/4NE1/4 sec. 27, T. 29 N., R. 118 W. Measured by W. W. Rubey, June 25, 1936]

Smiths Formation:

Upper, sandstone member (part):

Thickness

(feet)

12. Sandstone, hard, fine-grained, somewhat olivaceous; brown at base of ledge that makes prominent ridge

Lower, shale member:

11. Covered

10. Shale, black clay with few hard ferruginous concretions and sandy layers; no fossils found

9. Shale, tan clay

8. Limestone, hard; fossils abundant but difficult to collect

7. Shale, $\tan$ clay; like unit 5 , but no fossils noted

6. Limestone, like unit 8

5. Shale, tan clay; with highly fossiliferous ferruginous concretionary and more or less hardened layers of brown siltstone, particularly in upper half; fossil colln. 36-1 (Unios and gastropods):

USNM

Unio aff. $U$. hamili McLearn

Unio sp., triangular form

Goniobasis? aff. G.? ortmanni Stanton

Campeloma cf. C. harlowtonensis Stanton

"Kootenai" fauna (J. B. Reeside, Jr., written commun., 1937)

4. Shale, tan.clay, poorly exposed

3. Limestone, light-gray-weathering; much like Draney, but black on fresh surface and has bituminous odor

2. Poorly exposed. Red soil in upper two-thirds, grading to tan clay soil in lower third; very fine grained tan calcareous sandstone $1 \frac{1 / 2}{2}$ $\mathrm{ft}$ thick, approximately at middle of unit

Total lower, shale member

Total Smiths Formation measured

Draney Limestone (part):

1. Limestone, medium-gray, fine-grained; weathers to very light gray. Makes low hogback

\section{Reference section of the Smiths Formation}

[East of Smiths Fork Guard Station, SE1/4 sec. 23 and SW11/4 sec. 24, T. 29 N., R. 118 W. Measured by W. W. Rubey, Aug. 24, 1938]

Thomas Fork Formation (part):

Thickness

(feet)

12. Shale, poorly exposed, light-purplish-gray and pinkish variegated, sandy. Fragments of sandstone and conglomerate in tan to faintly pinkish sandy shale soil

Smiths Formation:

Upper, sandstone member:

11. Poorly exposed. Medium-gray soil with abundant fragments of tan and buff-gray quartzite and small light-gray limestone nodules

10. Block of white quartzite float, not more than $25 \mathrm{ft}$ below true position and possibly less than $5 \mathrm{ft}$; fossil collns. 38-18B (scales of gar pike) and 38-18C (dicotyledonous leaves) 
Smiths Formation - Continued

Upper, sandstone member - Continued

Thickness

(feet)

$25 \pm$

1

$2 \frac{1 / 2}{2}$

7. Shale, buff, gray, sandy, poorly exposed

6. Quartzite, olive-brown, very hard, massive, noncalcareous, and well-sorted sandstone. Grains show some recrystallization; uniformly $1 / 6-1 / 4 \mathrm{~mm}$ in diameter. Medium pale buff and gray where fresh, weathering to pale to medium buff. Individual beds 2-5 ft thick. Abundant rich brown and black lichens on weathered surfaces. Unit makes prominent ridge with abundant quartzite talus

Total upper, sandstone member 14

Lower, shale member:

5. Shale, black, fissile, poorly exposed; surface strewn with blocks of tan sandstone from above

4. Shale, gray to black, fissile, thin-bedded; contains medium-gray limestone nodules which weather medium buff gray. Fossil colln. 38-19 ("Kootenai-Cloverly" fauna. Field identification by J. B. Reeside, Jr.)

Total lower, shale member - _...

Total Smiths Formation

$\begin{array}{r}\frac{6}{526} \\ \hline 7551 / 2 \\ \hline\end{array}$

Smoot Formation of Eyer (1969, p. 1383):

3. Covered

2. Shale, calcareous, pink and variegated 25

Total Smoot Formation

Draney Limestone (part):

1. Shale, light- to medium-gray, calcareous; a few 6- to 12-in.-thick limestone beds

\section{Reference section of the Smiths Formation}

[31/4 miles southwest of Smiths Fork Guard Station, south-central part of sec. 33, T. 29 N., R. 118 W. Measured by W. W. Rubey, Aug. 9, 1938]

Thomas Fork Formation (part):

Thickness

(feet)

9. Mudstone and sandstone, variegated

Smiths Formation:

Upper, sandstone member:

8. Soil, tan sandy; alternating with 1- to 2-ft-thick beds of hard finegrained pale-buff-gray sandstone

$100+$

7. Sandstone, hard-white, fine-grained, calcareous; weathers pale buff gray

6. Soil, tan, sandy clay; contains small sandstone and white limestone chips

5. Limestone, medium-gray; weathers light gray; dense; has fetid odor. Fossils abundant but difficult to collect; colln. 38-22

4. Quartzite, olive-brown; pale-tan hard fine-grained sandstone with numerous buff, brown, and red stains on joint surfaces; brown impressions of plant stems (reeds)

3. Poorly exposed. Tan sandy soil and fragments of olive-brown quartzite

Total upper, sandstone member 
Smiths Formation - Continued

Lower, shale member (part):

2. Poorly exposed. Abundant black shale chips in soil

1. Shale, black; makes steep slope; fossil colln. 38-23 (bone

fragments) about $60 \mathrm{ft}$ below top

Total lower, shale member measured

Total Smiths Formation measured

$\frac{\frac{100+}{110+}}{311+}$

\section{THOMAS FORK FORMATION}

Also exposed in the hills along Smiths Fork is a unit here named the Thomas Fork Formation, for exposures along the Thomas Fork in the Cokeville quadrangle. The unit consists of banded and variegated red, purple, brown, and green mudstone and gray, tan, and buff sandstone which is conglomeratic in part with pebbles as much as 4 inches in diameter. The formation is characterized by pastel shades of the colors mentioned and abundant gray to brown limestone nodules as much as several inches in diameter.

The variegated mudstone and gray to buff sandstone beds of the Thomas Fork Formation may be easily distinguished from the beds of gray to tan abundantly fossiliferous sandstone and limestone and of gray sandstone, mudstone, and claystone of the overlying Cokeville Formation.

The type section (fig. 4) is that measured along the north bank of Thomas Fork, from the $\mathrm{SE}^{1 / 4} \mathrm{NE}^{1 / 4} \mathrm{NW}^{1 / 4} \mathrm{sec}$. 26 to the $\mathrm{SW}^{1 / 4} \mathrm{SW}^{1 / 4} \mathrm{NW}^{1 / 4} \mathrm{sec}$. 25, T. 28 N., R. 119 W. Evident here are not only strata typical of the Thomas Fork Formation but also the intertonguing relation between the upper part of the formation and the overlying unit. The main body of the Thomas Fork is about 1,080 feet thick at the type section, but it is overlain by the 573foot-thick lower tongue of the Cokeville Formation, described in the following measured section, and a 72-foot-thick upper tongue of the Thomas Fork. Although the Thomas Fork is about 2,000 feet thick farther north, on the southwest side of Star Valley, it thins southward to 350 feet in the Sage quadrangle. Its Early Cretaceous age is established by fossils in underlying and overlying units.

\section{Type section of the Thomas Fork Formation}

[At Thomas Fork, 21/2 miles above mouth of Salt Creek, from SE1/4NE1/4NW1/4 sec. 26 to SW1/4SW1/4 NW1/4 sec. 25, T. 28 N., R. 119 W. Measured by W. W. Rubey, Oct. 6 and 9, 1947]

Cokeville Formation upper tongue (part):

Thickness (feet)

58. Sandstone, medium-hard, massive to thin-bedded; weathers pale gray; medium grained; calcareous; abundant dark grains; crossbedded (from north)

Thomas Fork Formation:

Upper tongue:

57. Siltstone, red to almost chocolate-brown, calcareous; weathers fairly bright red. Red limestone nodules 3 in. across in upper $1 \mathrm{ft}$ of unit _._.

56. Sandstone, gray, medium-hard, calcareous, medium-grained; abundant dark grains 
Thomas Fork Formation - Continued

Upper tongue - Continued

Thickness

(feet)

55. Siltstone; in alternating red and gray beds $1-4 \mathrm{ft}$ thick. Gray beds contain soft coarse-grained medium-gray sandstone with abundant dark grains _...-

Total upper tongue of Thomas Fork Formation

Cokeville Formation:

Lower tongue:

54. Siltstone, pale-greenish-gray; $12 \mathrm{ft}$ above base unit contains 1 - $\mathrm{ft}$ thick bed of sandstone like unit 53

53. Sandstone, distinctly olive-green, medium-hard, massive, fine- to medium-grained, calcareous; weathers medium brown _._._._

52. Siltstone, pale-greenish-gray

51. Sandstone, medium-hard, brownish-gray-weathering, fine-grained, calcareous; abundant dark mineral grains

50. Siltstone, light-gray; surface strewn with sandstone blocks from above

49. Siltstone, light-gray _______ 80

48. Siltstone, gray; like unit 47 , but poorly exposed _____ 35

47. Siltstone, pale-greenish-gray, blocky, highly calcareous ____ 15

46. Sandstone; like unit 44 , but more massive and less hard _.__ $\quad 12$

45. Siltstone, gray, poorly exposed _._._.

44. Sandstone, hard, ledge-making, medium-grained, calcareous; abundant dark mineral grains. Thin bedded but hard throughout; weathers pale $\tan$ gray; lichens are on surface

43. Soil, gray, poorly exposed; like unit 42 , but has abundant chips and blocks of sandstone from above

42. Siltstone, medium- to light-greenish-gray, poorly exposę _._.-_

41. Covered

40. Sandstone, medium-gray, hard, massive, fine-grained, calcareous

Total lower tongue of Cokeville

Formation

Thomas Fork Formation:

Main body:

39. Poorly exposed. Alternate layers $2-5 \mathrm{ft}$ thick of (1) mediumgreenish-gray calcareous siltstone (weathers light gray) and (2) dull-red calcareous siltstone with a few thin $(1 / 4-2$ in.) beds of brown calcareous fine-grained sandstone. Whole unit weathers to a distinctly red soil. Red 2-ft-thick siltstone bed at top _._._-

38. Sandstone, medium-gray, thin-bedded, fine- to medium-grained, calcareous; abundant dark mineral grains

37. Poorly exposed. Light-gray sandy soil in upper part, red soil in middle, abundant fragments of sandstone like unit 36 in lower part

36. Sandstone, medium-gray, thin-bedded, medium-grained, calcareous; abundant dark minerals

35. Siltstone; light gray in upper half, medium gray in next one-sixth, dull pinkish gray in lower third

34. Sandstone, faintly greenish-gray, crossbedded, fine-grained; abundant dark grains. Contains limestone pebbles as much as $3 / 4$ in. in diameter in thin layers and along a few bedding surfaces _._-

33. Siltstone, pale-gray; upper $3 \mathrm{ft}$ darker gray with faint lavender cast

32. Sandstone, pale-gray, medium-hard, fine-grained, calcareous, crossbedded; many dark grains 


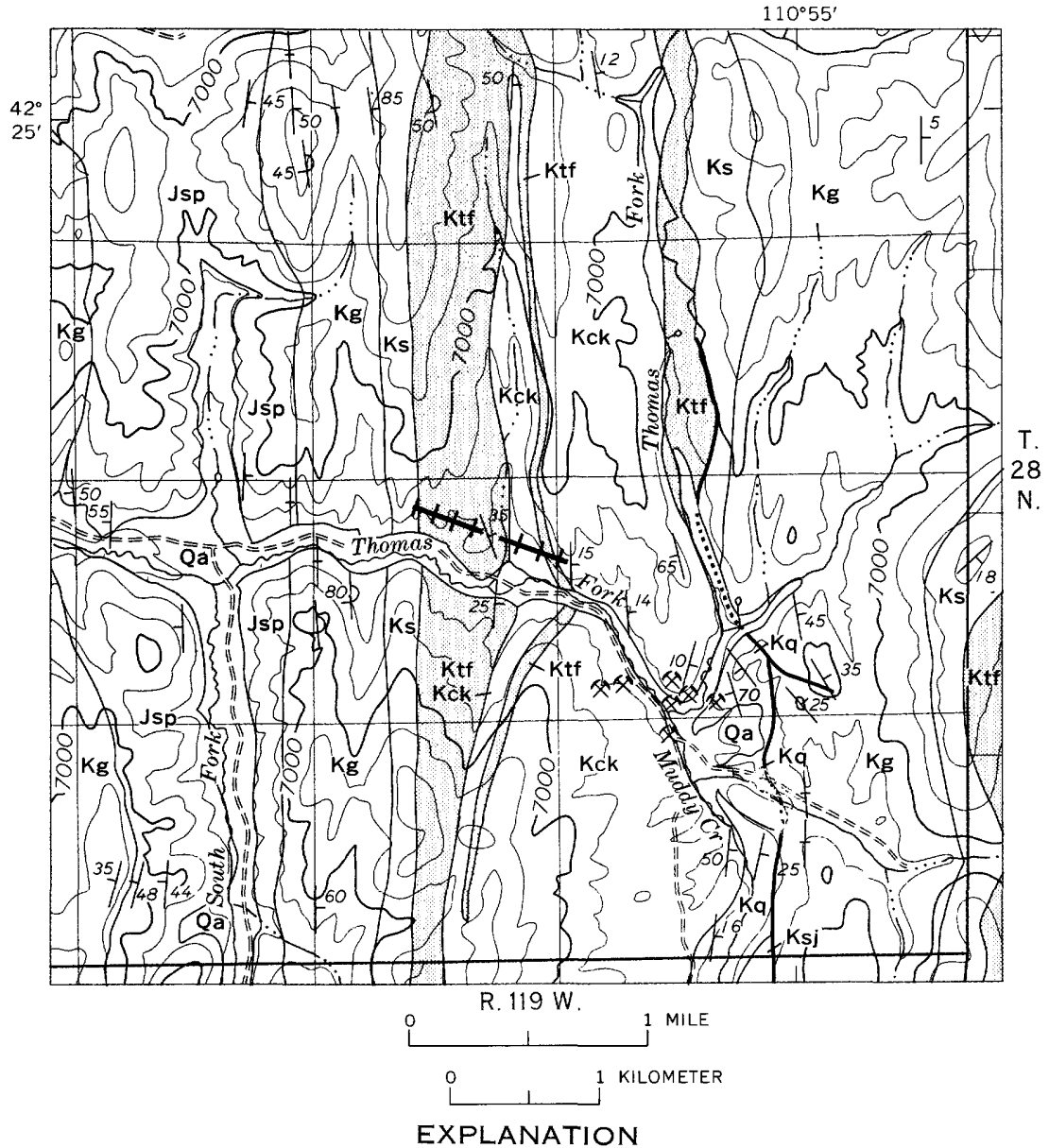

Qa Alluvium and colluvium - QUATERNARY

Ksj Sage Junction Formation

Kq Quealy Formation

Kck Cokeville Formation

Ktf Thomas Fork Formation

Ks Smiths Formation

Kg Gannett Group

RETACEOUS

Jsp Stump Sandstone and

Preuss Red Beds
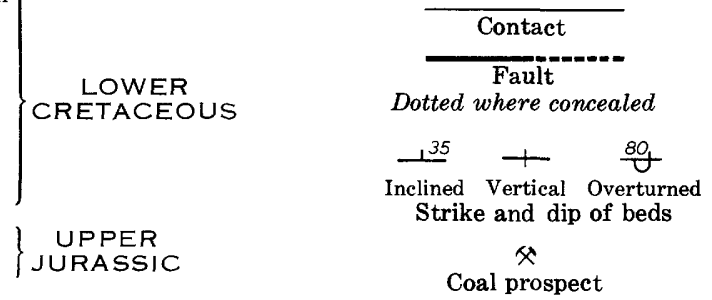

FIGURE 4. - Geologic map of the southeastern part of T. 28 N., R., 119 W., showing location of type section (line with crossbars) of the Thomas Fork Formation (stippled) in the Cokeville quadrangle. Contour interval, 200 feet. 
Thomas Fork Formation - Continued

Thickness

Main body - Continued

31. Soil, dull-reddish-gray; red siltstone bed, a few feet thick, about 10

$\mathrm{ft}$ below top

30. Poorly exposed. Most of interval is covered by dull-red soil; in basal few feet a gray thin-bedded sandstone

29. Siltstone, brick-red; contains nearly spherical light-gray sandy limestone nodules commonly $2-4$ in. in diameter. This red unit overlain by conspicuous pale-gray siltstone and that by faintly pinkish-gray, then light-gray siltstone with $1 \mathrm{ft}$ of medium-soft white sandstone at top

28. Sandstone, hard, thin-bedded, fine-grained, calcareous, crossbedded (from northwest); many dark grains. Abundant red clay pellets $1 / 4-1 / 2$ in. in diameter on some bedding surfaces. Becomes softer above and contains red sandstone in middle

27. Siltstone, red; abundant limestone nodules. Light-gray shale bed, a few feet thick, just below middle

26. Sandstone, thin-bedded, medium-grained, calcareous; many dark grains

24. Sandstone, medium-soft, thin-bedded, medium-grained, highly calcareous; abundant dark grains

23. Siltstone, pale-greenish-gray; and pinkish-tan soil nodules as much as $4 \mathrm{in}$. in diameter. Surface of nodules very irregular

21. Siltstone, pale-pinkish-gray, deep-maroon, and pale-lavender. Fossil colln. C15-47 (gastropods, fish scales, and bone fragments)

20. Sandstone, pale-buff

19. Siltstone; lavender in upper part, dull red in middle, and pale greenish gray in lower part; abundant limestone nodules

18. Sandstone, massive, buff-weathering; pale buff gray, both fresh and weathered. Fine grained, calcareous; few dark grains

17. Siltstone; lavender and medium gray in upper third, alternating red and light gray in lower two-thirds. A 2-ft-thick bed near middle is dull maroon. Limestone nodules, $3 / 8-5$ in. in diameter, especially abundant, the larger ones consisting of limestone pellets or fragments. The individual pellets are light gray, medium gray, and red and are $1 / 4-1 / 2$ in. in diameter

16. Sandstone, pale-greenish-gray, medium-grained, massive, buffweathering; relatively few dark grains. Almost noncalcareous _

15. Siltstone; dominantly red but with medium-gray to lavender beds, each 2-3 ft thick, just below middle and at top

13. Shale, sandy, pale-tan-gray; greenish-gray calcareous siltstone with abundant sandstone chips

12. Shale, dark-gray-red; weathers to lavender; succeeded by red soil above, then lavender again. Abundant limestone nodules in red soil. Discontinuous 2 -ft-thick sandstone beds 
Thomas Fork Formation - Continued

Main body - Continued

11. Sandstone, hard, medium-grained, calcareous, crossbedded; saltand-pepper aspect; weathers light buff gray; forms ledge _... 1

10. Siltstone, red _- 2

9. Sandstone, like unit 11

8. Siltstone, gray

7. Sandstone, like unit 11

6. Siltstone, gray-red, calcareous; weathers to light lavender. Lower part of unit dull pinkish gray; upper part, pale greenish gray -

5. Siltstone, reddish-brown, sandy, blocky, highly calcareous. Poorly exposed. Sandstone fragments only in lower part. Red soil and abundant small limestone nodules

4. Sandstone, hard, massive, fine-grained, calcareous; weathers pinkish brown

3. Shale, sandy, variegated; and limestone nodules

Total main body of Thomas Fork

Formation

Total main body and upper tongue

of Thomas Fork Formation

Smiths Formation (part):

Upper, sandstone member:

2. Shale, medium-gray; brown sandstone chips

1. Sandstone, hard, noncalcareous; sparkly salt-and-pepper aspect;

forms ridge. Grains $1 / 6-1 / 3 \mathrm{~mm}$ in diameter

Total Smiths Formation measured

\section{COKEVILLE FORMATION}

Above the variegated beds of the Thomas Fork Formation lies a mainly gray and tan unit here named the Cokeville Formation. The formation consists of light-gray- to tan-weathering medium-gray fossiliferous sandstone and sandy siltstone, light- to dark-gray claystone and mudstone, calcareous concretions, abundantly fossiliferous tan limestone, and some beds of lightgray, tan, and pink porcelanite and bentonite. In the upper part of the formation are a few beds of coal which were mined one-half mile west of Sage.

The beds of gray to tan fossiliferous sandstone and limestone and of gray sandstone, mudstone, and siltstone of the Cokeville Formation may be distinguished, north of the latitude of Cokeville, from the poorly exposed red and variegated mudstone and sandstone of the overlying Quealy Formation. From Cokeville southward the reddish-colored Quealy Formation is absent, and the Sage Junction Formation directly overlies the Cokeville Formation. In this southern area the two formations may be differentiated by the generally greater abundance of fossiliferous limestone and tan thin-bedded sandstone in the Cokeville and the greater abundance of porcelanite beds in the Sage Junction. The exact boundary is drawn at the base of the lowest thick interval of porcelanite and bentonite beds, which is continuous throughout the area and which, in the southernmost part, is more than 50 feet thick. 
The Cokeville Formation is moderately well exposed in the low hills east of Cokeville Butte, 2 miles northeast of the town of Cokeville for which it is named. The section here designated as the type (fig. 5) is that measured from the SE $1 / 4 \mathrm{SE}^{1 / 4} \mathrm{SW}^{1 / 4}$ to the NW1/4SW1/4 SW $1 / 4$ sec. 36, T. 25 N., R. 119 W., east of Cokeville Butte.

The formation is about 1,609 feet thick at the type section, but precise thicknesses are difficult to determine because the formation intertongues with and grades into both underlying and overlying units which thicken northward at the expense of the Cokeville; formational boundaries, therefore, are arbitrary. Fossils from this type locality have been described by Yen $(1954$, his locality 10, p. 46, and division 2, p. 48, 49). In the Sage quadrangle the formation is $1,900-2,500$ feet thick. Fossils from the formation are similar to those in the Bear River Formation east of the Absaroka fault and are assigned an Early Cretaceous age (Cobban and Reeside, 1951. See, however, Yen, 1954, p. 49, 50).

\section{Type section of the Cokeville Formation}

[2 miles northeast of Cokeville along the north side of Smiths Fork, SW/4 sec. 36, T. 25 N., R. 119 W. Measured by W. W. Rubey, Sept. 24, 1949]

Quealy Formation (part):

Thickness (feet)

48. Soil, grayish-red; distinctly different from underlying units. Alternation in beds $1 / 2 \mathrm{ft}$ to several feet thick of dull-gray-red and lightgreenish-gray calcareous siltstone

Cokeville Formation:

47. Faintly pinkish gray soil at base, then light-gray sandy soil like unit 46 , but also some pale-green soil

46. Soil, light-gray, sandy; obscure exposures of pale-tan-gray siltstone in upper third

45. Dark-gray shale in upper part. Light-gray silty calcareous shale and soft thin-bedded gray iron-stained sandstone in middle part; unit has been prospected for coal. Dark-gray soil in lower part includes black shale dump

44. Soil, light-tan, sandy

43. Sandstone, hard, thin-bedded

41. Coquina of oyster shells

40. Soil, light-tan-gray; contains sandstone fragments, several thin zones of dark-gray shale

39. Sandstone, light-gray, hard; weathers tan

38. Soil, light-tan-gray, sandy

37. Porcelanite, dark-gray, hard

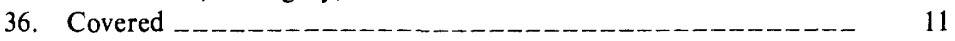

35. Sandstone, tan, medium-grained, hard; some clay pellets _-_-_ 32

34. Covered. Old coal prospect in lower part _

33. Sandstone, tan, hard, calcareous, medium-grained _-_-_-_- 6

32. Covered _._. 45

31. Sandstone, $\tan$

30. Covered by coal dump ___ 32

29. Sandstone, gray, thin-bedded, carbonaceous 


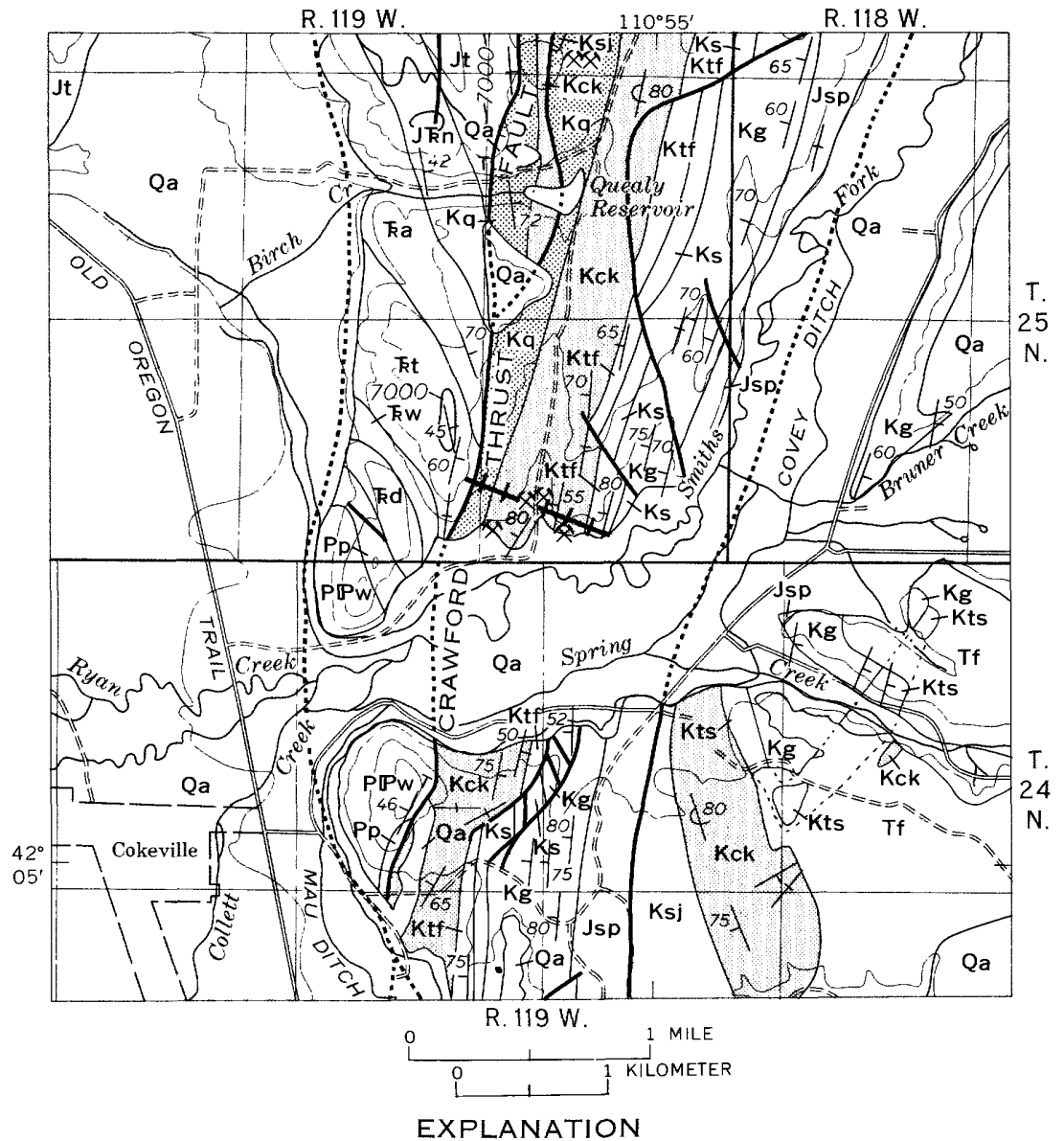

Qa Alluvium and colluvium-QUATERNARY

Tf Fowkes Formation - TERTIARY

Ksj Sage Junction Formation,

Kq Quealy Formation

Kck Cokeville Formation

Ktf Thomas Fork Formation

Ks Smiths Formation

Kts Thomas Fork and Smiths Formations

Kg Gannett Group

Jsp Stump Sandstone and

Preuss Red Beds

Jt Twin Creek Limestone

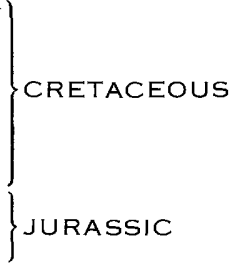

Jkn Nugget Sandstone-JURASSIC (?) AND TRIASSIC (?)

Ka Ankareh Red Beds

Kt Thaynes Limestone

Kw Woodside Red Beds

Kd Dinwoody Formation

Pp Phosphoria Formation - PERMIAN

PPW Wells Formation - PERMIAN AND PENNSYLVANIAN

Conitact

Dotted where concealed

\section{Fault}

Dotted where concealed

Thrust fault

Dotted where concealed

$\mathrm{T}$, on upper plate

$\frac{45}{\text { Inclined }} \stackrel{80}{\text { Overturned }}$

Strike and dip of beds

x

Coal prospect

FIGURE 5. - Geologic map of the Cokeville area, showing location of type sections (line with crossbars) of the Cokeville (light stipple) and Quealy (heavy stipple) Formations. Contour interval, 200 feet. 
Cokeville Formation - Continued

28. Sandstone, thin-bedded. Main mine portal enters eastward through these beds

27. Soil, light-tan, sandy. Dump with bony coal fragments in middle of unit

26. Sandstone, light-tan, soft, thin-bedded

25. Soil, tan, sandy; abundant sandstone fragments. Dark-gray to black carbonaceous zone in lower $5 \mathrm{ft}$. Dump with bony coal fragments

24. Limestone, tan, thin-bedded, silty, soft _.....................

23. Soil, light-tan, sandy

22. Carbonaceous zone, dark-gray _._._-

21. Limestone, brown, silty, concretionary, fossiliferous _......-

20. Siltstone, medium-gray, soft; silty sandstone. A tan zone 6 in. thick near middle

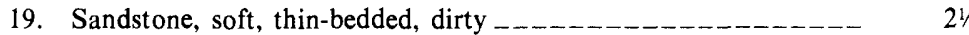

18. Siltstone, soft, gray, tan, calcareous ___ 3

17. Limestone, tan-weathering, silty; coquina beds with Pyrgulifera $-\quad 2$

16. Siltstone, light-tan-gray, calcareous ___ 28

15. Carbonaceous and coal zone. Main prospect. Fossil colln. R49-49 (Pyrgulifera)

14. Limestone, tan-weathering, silty. Fossil colln. R49-50 (Campeloma. Field identification by J. B. Reeside, Jr.) _._._-

13. Siltstone, light-gray _._.

12. Limestone, tan, sandy, hard _.

11. Shale, light-gray, calcareous

10. Limestone, tan, sandy

9. Carbonaceous zone and coal. Minor prospect entry

8. Limestone, hard, like unit 6; fossiliferous (large gastropods) --_-

7. Shale, medium-gray _-

6. Limestone, medium-brownish-gray, hard, silty; weathers very light gray _._.

5. Soil, light-gray, sandy ___ 19

Total Cokeville Formation _.

Thomas Fork Formation (part):

4. Soil, light-gray, sandy; 1 -ft-thick red zones $16 \mathrm{ft}$ above base and at top of unit

3. Soil, red, sandy

2. Soil, light-gray, sandy; limestone nodules as in unit 1 . Contains 6 -ftthick very light gray, soft, calcareous sandstone just below middle. Numerous pale-salmon-pink calcite vein fragments

1. Siltstone, soft; alternating pale-gray-red and light-gray with abundant small limestone nodules $(1 / 4-1$ in. in diameter)

\section{QUEALY FORMATION}

The Cokeville Formation is directly overlain in the northern part of the region but not in the south by a unit of red beds here named the Quealy Formation for the exposures 11/4 miles south of Quealy Reservoir in the SE1/4 sec. 35 and the SW $1 / 4$ sec. 36 , T. 25 N., R. 119 W., in the Cokeville quadrangle, here designated the type section (fig. 5). Some other moderately well exposed sections of the formation are along First, Second, and Third Creeks in the westernmost part of T. 26 N., R. 118 W. A section 
of about 1,200 feet of beds between the Cokeville and Sage Junction Formations 1 mile north of Quealy Reservoir is designated as a reference section. The unit consists of red and variegated pastel-tinted mudstone and pink, gray, and tan sandstone.

The red-tinted soils of the poorly exposed Quealy Formation contrast with, and distinguish it from, the better exposed beds of the overlying Sage Junction Formation, which is dominantly gray sandy siltstone and sandstone but which includes many thin beds of white, gray, green, and pink porcelanite.

The formation is about 1,000 feet thick in the northern part of the Cokeville quadrangle, but it grades out southward and is absent south of the latitude of Cokeville; it is regarded as a southward-extending tongue of the Wayan Formation (Mansfield, 1927, p. 105). The formation is very probably equivalent to the lower part of the Aspen Shale, for it includes fossil trunks of Tempskya at numerous localities. It is of Early Cretaceous age, as shown by fossiliferous strata above and below.

\section{Type section of the Quealy Formation}

[11/4 miles south of Quealy Reservoir, SE1/4 sec. 35 and SW1/4 sec. 36, T. 25 N., R. 119 W. Measured by W. W. Rubey, Sept. 24, 1949]

Thaynes Limestone (part):

Thickness

13. Siltstone, hard, calcareous

Crawford thrust fault.

Quealy Formation (part):

12. Soil, very faintly pink; covered with chips of Thaynes tan siltstone and gray sandstone from immediately above _._._._. 46

11. Soil, red _____ 73

10. Poorly exposed; largely red soil __- 97

9. Soil, light-gray, sandy. Contains green siltstone beds _-_-_- 65

8. Sandy soil; distinctly red zone

7. Soil, light-gray, sandy. Includes one red zone $3 \mathrm{ft}$ thick $30 \mathrm{ft}$ below top

6. Soil, light-gray, sandy; alternating with five dull-pinkish-gray zones

5. Two red zones, each about $4 \mathrm{ft}$ thick, separated by very light gray weathering siltstone

4. Soil, very light gray, sandy; faintly reddish zone near middle. Siltstone very light distinctly greenish gray

3. Soil, grayish-red; distinctly different from underlying units. Alternation in beds $1 / 2 \mathrm{ft}$ to several feet thick of dull-gray-red and lightgreenish calcareous siltstone

Cokeville Formation (part):

Total Quealy Formation below Crawford thrust fault

2. Faintly pinkish gray soil at base, then light-gray sandy soil like unit 1, but also some pale-greenish soil

1. Soil, light-gray, sandy; obscure exposures of pale-tan-gray siltstone in upper third

Total Cokeville Formation measured 


\section{SAGE JUNCTION FORMATION}

The Quealy Formation north of Cokeville and the Cokeville Formation south of Cokeville are directly overlain by the Sage Junction Formation, named here for exposures at the highway junction $1 \frac{1}{2}$ miles west of Sage. The formation consists of light-gray and locally tan calcareous sandy siltstone and fine to very fine but partly medium-grained sandstone and quartzite; light-gray, tan, and grayish-red mudstone and claystone; some thin beds of grit and conglomerate in the upper part; numerous thin beds of white, gray, and green to pink porcelanite through all but the uppermost several hundred feet of the formation; and a few beds of brown to gray fossiliferous limestone. A few beds of coal are present in the lower part and have been mined at several localities along Boulder Ridge from near Sage to Antelope Creek. ${ }^{2}$

The section measured along the south end of Boulder Ridge, on the north side of U.S. Highway $30 \mathrm{~N}$ at Sage Junction, from the NE1/4 NW1/4 SE $1 / 4$ to the NW1/4SW1/4NW1/4 sec 7, T. 21 N., R. $119 \mathrm{~W}$., is here designated the type (fig. 6). Preserved unconformably beneath Tertiary strata is 2,270 feet of beds; on the west, the unit is overlain by Quaternary sediment. The formation is overlain with angular unconformity by Tertiary and Quaternary strata everywhere else that it has been examined. Total thicknesses deposited, therefore, are not known. An additional 1,100 feet of beds, higher than those at the type section, is preserved 4 miles north-northeast, along the unnamed northwest-flowing stream in sec. 20, T. 22 N., R. 119 W.; this approximately 3,400 -foot-thick section is here designated a reference section. Fossils indicate that the Sage Junction Formation is Early Cretaceous in age. That the formation is correlative in large part with much of the Aspen Shale is suggested by the abundance of porcelanite beds in both as well as by invertebrate fossils (J. B. Reeside, Jr., oral commun.; Yen, 1951, 1952, 1954).

It is distinctly possible that the uppermost several hundred feet of the formation may be equivalent in age and lithologic character to parts of the Frontier Formation, which overlies the Aspen Shale farther east. At places where the greatest thicknesses of the formation are exposed (at discontinuous exposures from sec. 29, T. 22 N., R. 119 W., northward for 6 miles to sec. 28 , T. 23 N., R. 119 W., Wyoming; from Third Creek in sec. 12, T. 26 N., R. 119 YV., northward for 5 miles to sec. 13, T. 27 N., R. 119 W., Wyoming; and near the head of Tincup Creek in Idaho, 50 miles farther to the northwest) the porcelanite beds characteristic of most of the formation do not extend higher than about 2,600 feet above the base. Furthermore, layers of grit and conglomerate are more numerous in these upper beds than in those below, and dicotyledonous leaves were noted at several localities $\left(\mathrm{NW}^{1 / 4}\right.$ sec. 20 and NE1/4 sec. 17, T. 22 N., R. 119 W., Wyoming; SE1/4 sec.

\footnotetext{
${ }^{2}$ The coal bed mined at Sage may have been the origin of the name for the town of Cokeville. Mr. Albert Mau, a stockman in the region, believes that signs for the railroad sidings Sage and Cokeville along the Oregon Short Line were inadvertently reversed when the railroad was being built.
} 
12, T. 26 N., R. 119 W., Wyoming, and sec. 19, T. 5 S., R. 44 E., Idaho, about 2 miles southeast of Wayan Post Office). The leaves from the locality near Wayan Post Office are in strata near the top of an approximately

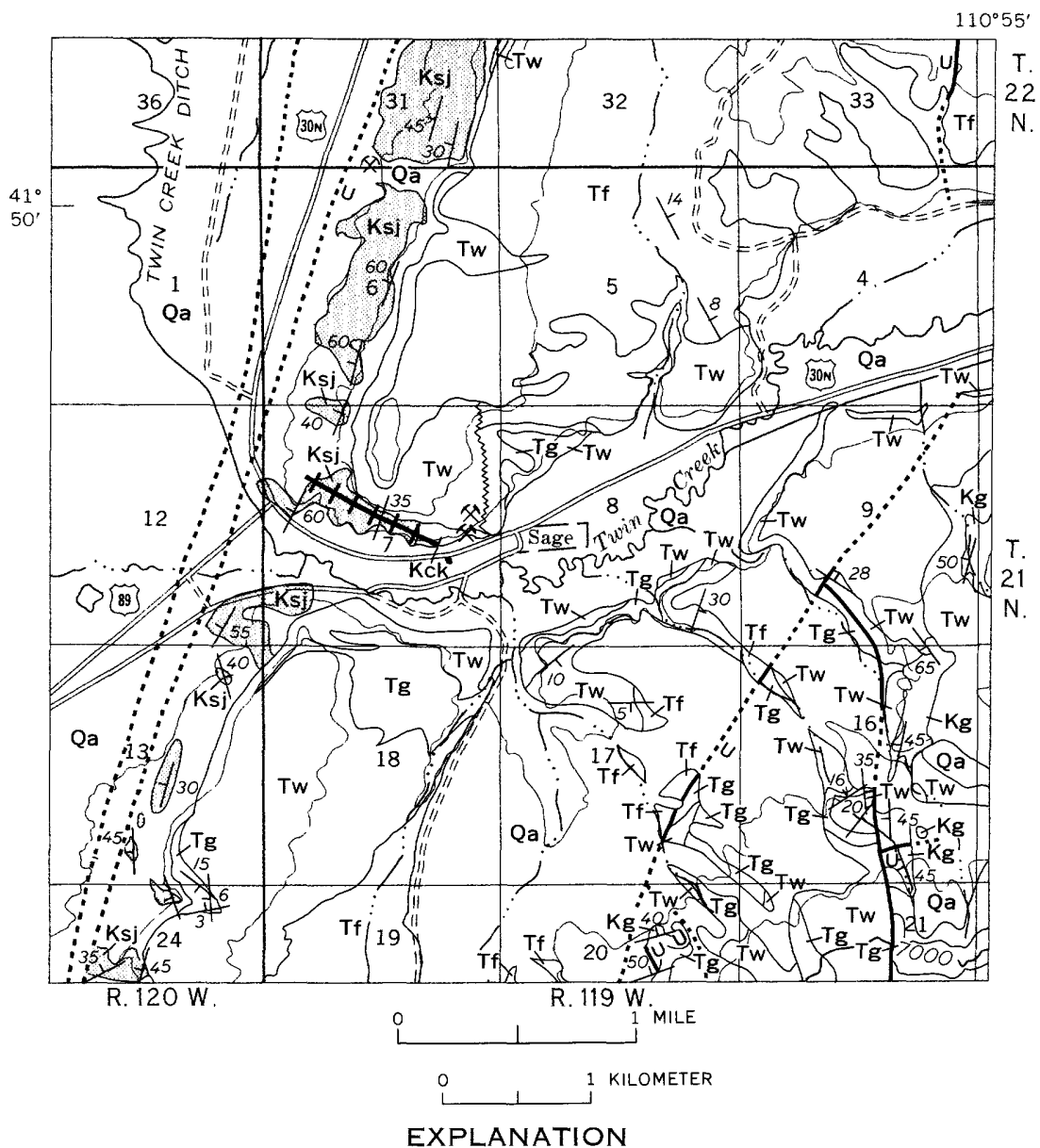

Qa Alluvium and colluvium-QUATERNARY

Tf Fowkes Formation

$\left.\begin{array}{ll}\text { Tf } & \text { Fowkes Formation } \\ \text { Tg } & \text { Green River Formation } \\ \text { Tw } & \text { Wasatch Formation }\end{array}\right\}$ TERTIARY

Ksj Sage

Kck Cokeville Formation

Kg Gannett Group

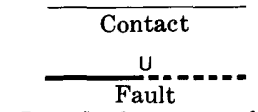

Dotted where concealed $\mathrm{U}$, upthrown side

$\frac{35}{\text { Strike and }}$
dip of beds

x

Coal prospect

FIGURE 6. - Geologic map of the Sage area, in the southwestern part of the Sage quadrangle, showing location of type section (line with crossbar) of the Sage Junction Formation (stippled). 
2,000-foot-thick section of light-gray siltstone, shale, sandstone, and porcelanites which yield numerous Tempskya trunks and which are in many respects similar to the Sage Junction Formation as it is exposed to the southeast in western Wyoming. The leaves from this locality were identified by the late R. W. Brown (written commun., Nov. 8, 1940) as follows:

\section{USNM 8589}

Nilssonia? sp.

Platanus sp.

Artocarpus sp.

Liriodendron sp.

Fragments of other species of dicotyledons

Stems or roots

His interpretation was that "this group of fossils indicates an age between that of the Dakota sandstone and the Mesaverde formation." Although this age assignment certainly does not prove that these uppermost beds of the Sage Junction Formation are equivalent in age to the Frontier Formation, they are at least consistent with that interpretation.

These uppermost beds of the Sage Junction Formation are especially conglomeratic north and south of Third Creek, in secs. 12 and 18, T. 26 N., R. $119 \mathrm{~W}$.

The Sage Junction Formation is not simply another name for the Aspen Shale. The two formations differ in several significant respects. (1) Although the total number and thickness of porcelanite beds may be roughly the same in the two formations, these beds make up a much smaller part of the Sage Junction because of its greater thickness. (2) The Quealy Formation, which underlies the Sage Junction in the northern part of the region, is very probably equivalent in age, though not in composition, to part of the Aspen. (3) Farther south, where the Quealy has pinched out, the Cokeville Formation underlies the Sage Junction and very probably includes beds equivalent to part of the Aspen. (4) The absence of porcelanite beds and the presence of gritty sandstone and dicotyledonous leaves suggest that the upper several hundred feet of the Sage Junction may be equivalent to the lower part of the Frontier Formation.

\section{Type section of the Sage Junction Formation}

[Sage Junction (of U.S. Highways $30 \mathrm{~N}$ and 89 ), NW1/4SE1/4 and $\mathrm{S}^{1 / 2} \mathrm{NW}^{1 / 4}$ sec. 7, T. 21 N., R. 119 W. Measured by W. W. Rubey, Aug. 30, 1949, and Sept. 17, 1949]

Top of exposure.

Sage Junction Formation:

Thickness

63. Siltstone, light-tan, sandy; faintly greenish tint

62. Siltstone, faintly reddish-gray

61. Siltstone, light-tan, sandy

60. Siltstone, faintly reddish-gray

59. Siltstone, light-tan, sandy; relatively common tan sandstone blocks -

58. Clay, medium-gray, bentonitic-weathering

57. Siltstone, light-tannish-gray 
Sage Junction Formation - Continued

Thickness

(feet)

56. Sandstone, tan

55. Siltstone, gray, tan, sandy; a few thin sandstone beds and a few thin dark-gray siltstone beds

54. Bentonite and porcelanite. Bentonitic-weathering clays in upper and lower fourths; abundant porcelanite chips in middle half of unit --

53. Siltstone, light-tan, sandy; several 6-in.-thick beds of brown-weathering sandstone. Fossil collns. R49-69 and Y16A (leaves) from $6 \mathrm{ft}$ above base of unit

52. Sandstone, fine-grained, calcareous, hard; weathers dark brown. Fossil collns. R49-68 and Y16B (Unios, a molluscan fauna of six species described by Yen, 1952, p. 349)

51. Siltstone, light-tan, sandy

50. Soil, light-tan, sandy. Poorly exposed

49. Sandstone, crossbedded, calcareous, tan, medium-hard, mediumgrained $(1 / 4 \mathrm{~mm}$ in diameter)

48. Siltstone, sandy, light-tan-gray. Old coal prospect in upper part shows only light-gray siltstone

47. Sandstone, brown-weathering; contorted bedding at top and bottom, $2 \frac{1}{2}$-ft-thick bed of soft light-tan-gray sandy shale in middle

45. Sandstone, light-tan-gray, hard, massive to thin-bedded; weathers medium brown

34. Soil, light-gray, sandy

33. Porcelanite, slightly calcareous, medium-gray; weathers light gray. Minute gastropods and fragments of larger mollusks. Fossil collns. Y24A and Y24B (a nonmarine molluscan fauna of 20 species in 14 genera described by Yen, 1952)

31. Sandstone, brownish-gray, hard, calcareous; scattered black chert pebbles as much as $1 / 2$ in. in diameter

30. Soil, light-tannish-gray, sandy; fragments of poorly consolidated sand

28. Sand, tan, poorly consolidated, calcareous, medium-grained (average diameter $1 / 3 \mathrm{~mm}$ )

26. Covered

25. Porcelanite, fine- and medium-grained; abundant biotite flakes in the medium-grained material. The fine material strikingly banded by alternation of thin light- and dark-gray layers

24. Soil, light-gray, sandy 
Sage Junction Formation - Continued

Thickness (feet)

24

295

25

100

50

8

41

25

14. Sandstone, medium-hard, medium-grained; in beds $1 / 2-2 \mathrm{ft}$ thick that alternate with soft sandy siltstone in beds $1-2 \mathrm{ft}$ thick. Fossil colln. R49-67 from basal bed (Unio and dicotyledon leaf. Field identification by J. B. Reeside, Jr.)

13. Soil, light-gray, sandy

10

38

56

11. Poorly exposed. Contains light-tan and pink bentonitic-weathering soil and abundant fragments of porcelanite and fine-grained tan slightly calcareous sandstone

8. Soil, light-gray, bentonitic-weathering greenish $\tan$

7. Soil, light-gray, bentonitic-weathering

5. Soil, light-gray, bentonitic-weathering; abundant fragments of mediumto dark-gray to pale-grayish-pink porcelanite in lower part. Tempskya fragments

NOTE. - The lowest thick zone of porcelanite and bentonite is represented in this section by the $58 \mathrm{ft}$ of units $5-11$.

Total Sage Junction Formation

3. Sandstone, medium-gray, hard, calcareous; weathers dark brown --

2. Soil, conspicuous light-gray, fine sandy -

1. Alternating (1) sandstone, light-tan, fine-grained (average diameter $1 / 20$ $\mathrm{mm}$ ); black grains and small white flecks, crossbedded, somewhat contorted; beds $1 / 2-1 \frac{1}{2} \mathrm{ft}$ thick, and (2) light-tan sandy siltstone; beds $2-10 \mathrm{ft}$ thick. Some dense light-tan-gray calcareous concretions, slightly septarian

Total Cokeville Formation measured

\section{UPPER CRETACEOUS}

Upper Cretaceous rocks in the central and southern parts of the western Wyoming thrust belt have commonly been assigned to the Frontier Formation and the overlying Hilliard Shale and Adaville Formation (Veatch, 1907 , p. 65-67; Schultz, 1914, p. 60-68). In the northern part of the region, however, differences in composition make a threefold division so 
difficult that the hyphenated designation "Adaville-Frontier formation" was used for the Bedford quadrangle (Rubey, 1958). The clues to understanding the regional relations have emerged from recognition of facies changes within the Hilliard Shale.

The Frontier Formation is about 2,200 feet thick at its type locality and consists dominantly of interbedded white and brown sandstone, tan siltstone, and dark-gray claystone; layers of lignite, coal, and some porcelanite are also present. The Hilliard Shale, about 6,600 feet thick in the Kemmerer area, consists dominantly of dark- to medium-gray and tan marine claystone and somewhat lighter siltstone and includes some laminae and beds of white to dark-gray sandstone and white to gray bentonite. The Adaville Formation, about 2,900 feet thick at its type locality, consists, somewhat like the Frontier, of interbedded yellow, brown, and gray sandstone, siltstone, partly carbonaceous claystone, and layers of coal.

Near the middle of the Hilliard Shale along Hams Fork is a comparatively thin but ledge-forming tongue of mainly sandstone that was recently named the Shurtliff Member of the Hilliard Shale by Smith (1965, p. 14). This sandstone unit pinches out within 7 miles south of Hams Fork, which probably explains why it was not given greater attention by Veatch (1907, p. 70 and pl. 3). Where exposed at the type locality along Hams Fork, in sec. 27, T. 22 N., R. 116 W., the Shurtliff Member, here adopted as the Shurtliff Sandstone Member, is about 800 feet thick and consists of sandstone ledges in the lower 264 feet, dark-gray claystone and siltstone in the middle 367 feet, and sandstone ledges in the upper 173 feet. As the member is traced northward along strike, the middle shale intertongues with sandstone, and large fossil oyster shells increase in abundance. Shale beds above and below the member along Hams Fork also intertongue northward with sandstone beds so that increasingly greater proportions of Hilliard are assigned to the middle sandstone unit northward. Uppermost beds of the Hilliard also intertongue northward with sandstone beds assigned to the Adaville Formation (fig. 7). Recognition of these relations (Andrews, 1944; Cobban and Reeside, 1952, p. 1934) resulted in the designation in the Bedford quadrangle (Rubey, 1958) of the "AdavilleFrontier formation," a sequence of sandstone, siltstone, claystone, and coal which contains no recognizable Hilliard Shale. It is now proposed (in the following section) to assign these rocks to the Blind Bull Formation.

Northward decrease in the abundance of claystone is accompanied by increase in the number and clast size of grit and conglomerate beds. The clasts are composed mainly of medium- to dark-gray chert. Grit beds are present as far south as the southeastern part of the Kemmerer quadrangle. The coarsest material noted is in the SE1/4 sec. 19, T. 25 N., R. 115 W., in a bed 22 feet thick, approximately 1,630 feet above the base of the Shurtliff Sandstone Member of the Hilliard Shale. The pebbles and boulders in this bed range in diameter from less than 1 inch to 15 inches, but are chiefly 3-6 
inches, and consist of subrounded to well-rounded clasts of white, tan, red, and brown quartzite and white, gray, red, and black chert.

\section{BLIND BULL FORMATION}

Formal definition of a new term to replace the unsatisfactory hyphenated designation "Adaville-Frontier formation" (Rubey, 1958) seems desirable to promote understanding of regional stratigraphic relations and to provide for forthcoming maps. The sequence of partly conglomeratic sandstone, siltstone, claystone, coal, and bentonite above the Aspen Shale is here named the Blind Bull Formation for exposures 3 miles north of the Blind Bull coal mine in the northeastern part of the Afton quadrangle (Rubey, 1973).

New names are not proposed here for the greatly thinned remnants of the Hilliard Shale in the northeastern part of the region. These remnants differ in no significant way from the typical Hilliard Shale of the southern part of the region and therefore they are designated as upper and lower tongues of the Hilliard.

The question remains as to how best to treat the sequence of beds of gray to buff calcareous sandstone and sandy siltstone and some black carbonaceous shale and coal which, in the northeastern part of the area east of the Wyoming Range, lies above the Aspen Shale and below the lower tongue of the Hilliard. In this area this sequence could be assigned accurately to the Frontier Formation. In the exposures west of the Wyoming Range, however, no tongues of the Hilliard Shale have been recognized, and therefore this treatment is not feasible. Consequently, I propose to apply, somewhat arbitrarily perhaps, the name Blind Bull Formation to the sequence of Cretaceous sandstone, sandy siltstone, and coal beds lying above the Aspen Shale, both west and east of the Wyoming Range.

One of the best exposed sequences of these strata is that measured along the divide between Horse Creek and the Hoback River, along the north margin of the Afton quadrangle ${ }^{3}$ from the $\mathrm{SW}^{1 / 4}$ sec. 18 , T. 35 N., R. 115 W., to the $\mathrm{S} 1 / 2$ sec. 23, T. $35 \mathrm{~N}$., R. $116 \mathrm{~W}$., here designated the type section (fig. 8). Preserved in this section east of and beneath the trace of the Darby thrust fault is about 6,200 feet of beds that contain not only fossils but also two tongues of the Hilliard Shale which document the regional relations of the unit. The base of the lower tongue of the Hilliard, 975 feet thick, lies about 1,143 feet above the base of the Blind Bull Formation; that of the upper tongue of the Hilliard, more than 135 feet thick, lies about 6,058 feet above the base of the Blind Bull.

Fossils were collected from a bed about 250 feet above the base of the upper tongue of the Hilliard Shale at a locality $3 \frac{1}{2}$ miles south of Deadman Mountain, in the $\mathrm{SW}^{1 / 4} \mathrm{SE}^{1 / 4} \mathrm{sec}$. 3, T. 34 N., R. $116 \mathrm{~W}$. They were identified

\footnotetext{
'The sequence of Cretaceous rocks exposed at this locality has also been measured by Ross and St. John (1960, p. 50--51) and Frerichs and Steidtmann (1971, p. 163-165).
} 


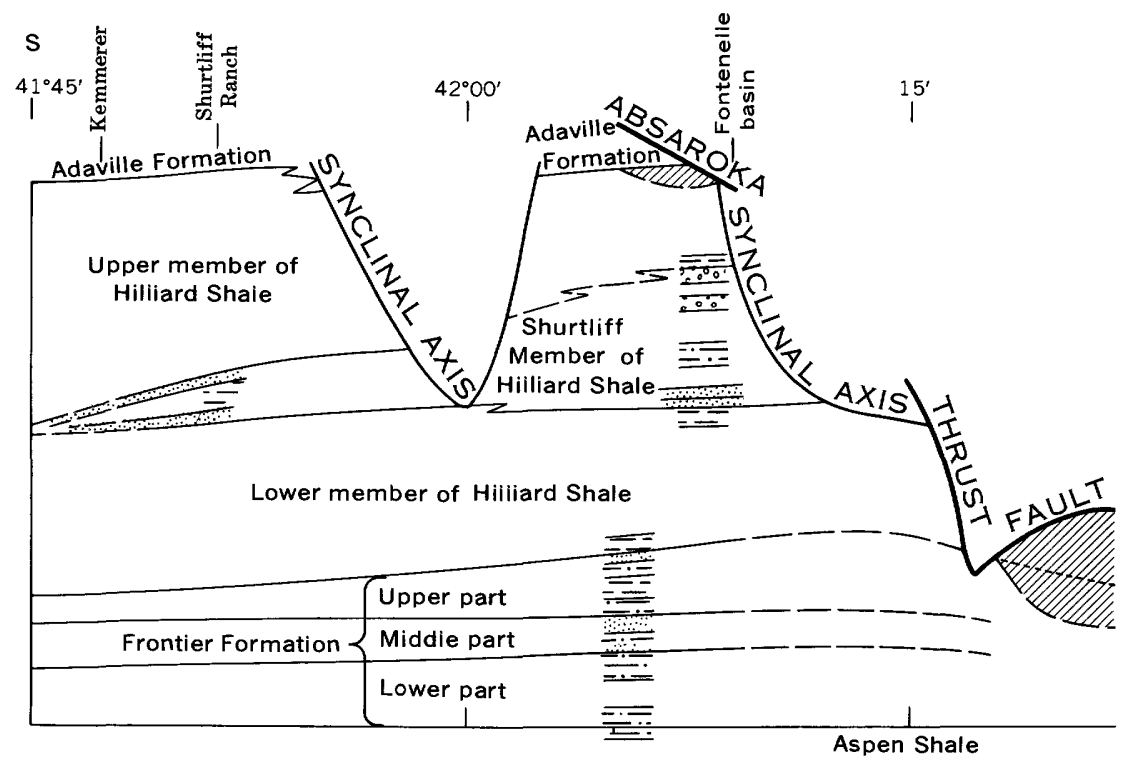

EXPLA N A TION

LITHOLOGIC SYMBOLS
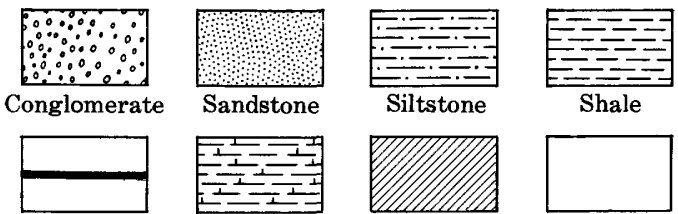

Sandstone

Siltstone

Shale

Coal
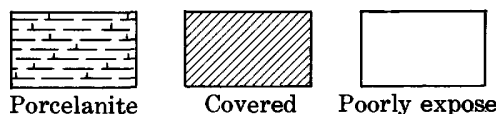

Poorly exposed
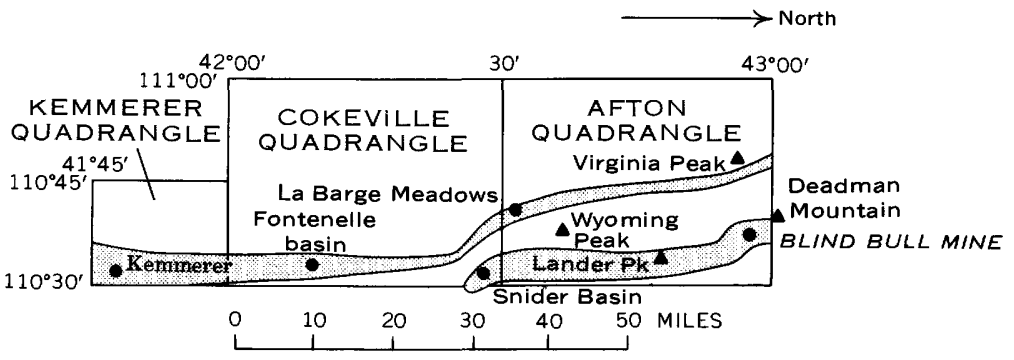

FiguRE 7. - Lateral relationships of Upper Cretaceous formations in the Kemmerer, heavy lines, thrust faults above 


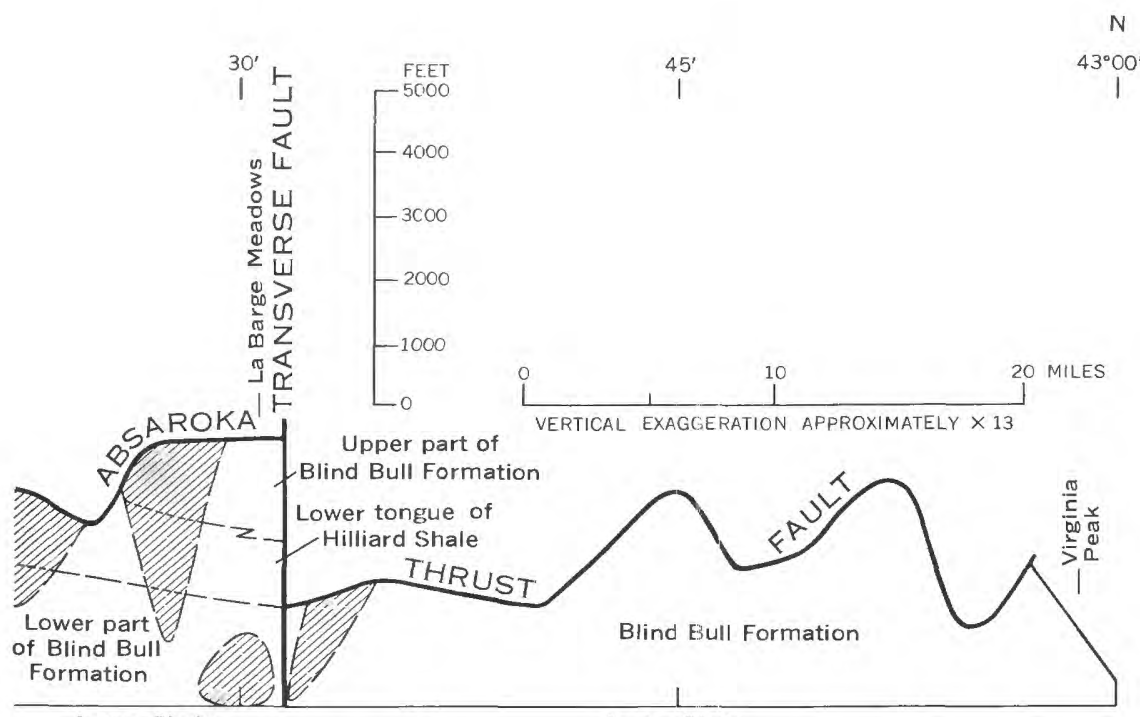

Aspen Shale

Aspen Shale

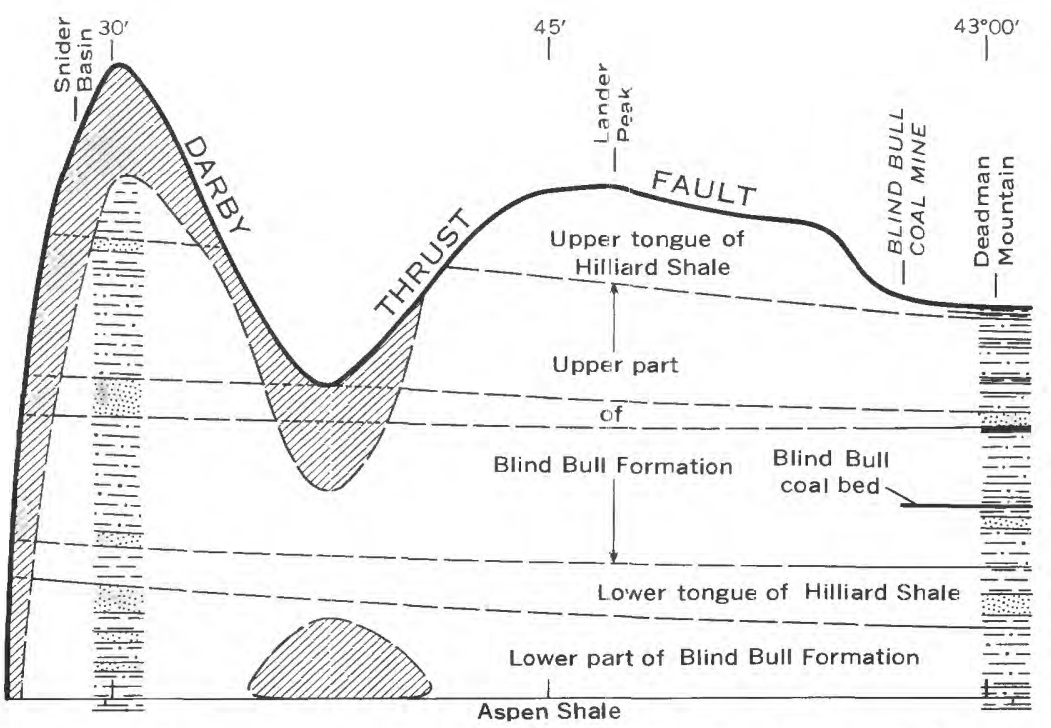

Cokeville, and Afton quadrangles. Lithologic symbols indicate sites of measured sections; preserved Upper Cretaceous rocks. 

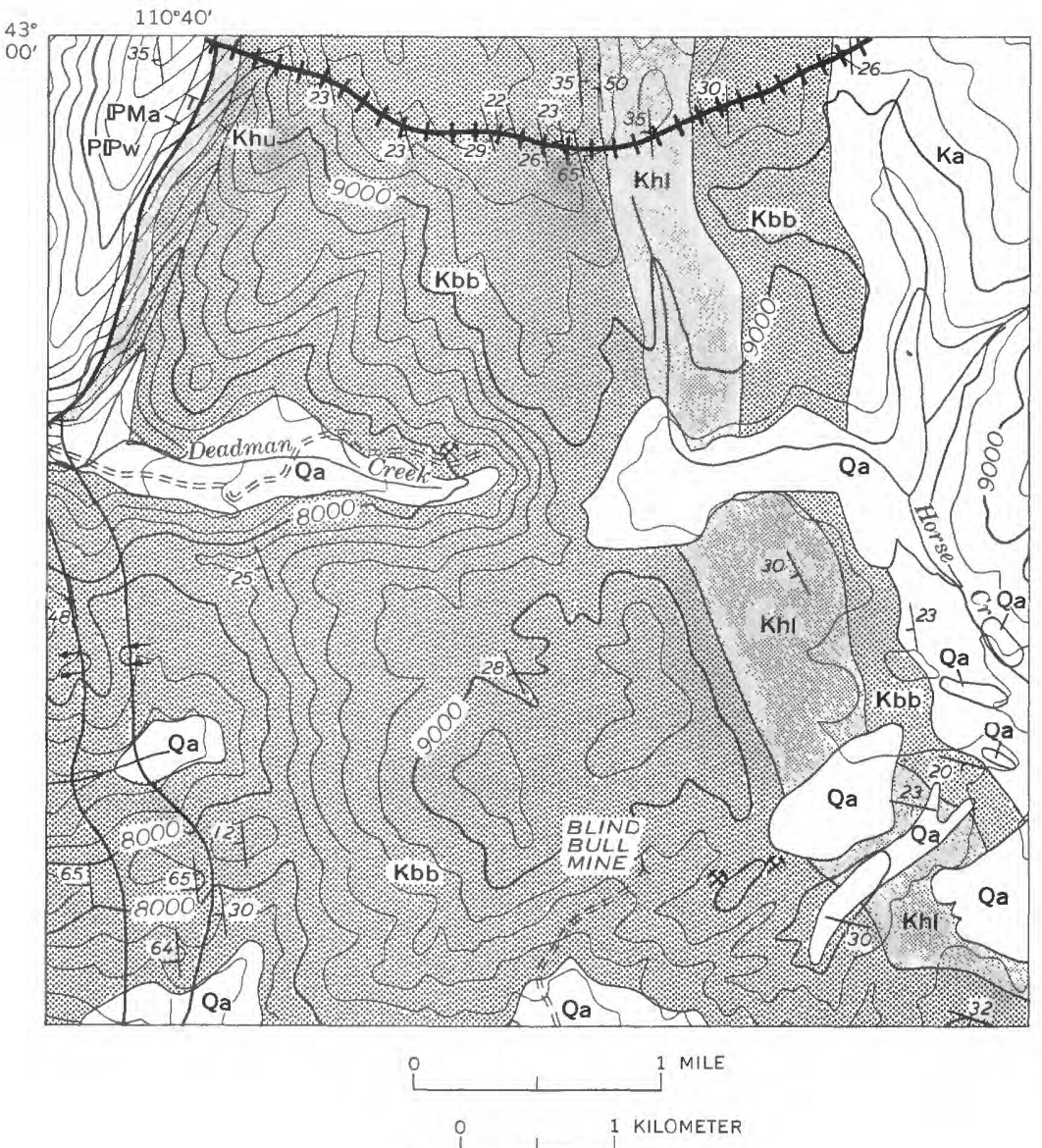

\section{EXPLANATION}

Qa Alluvium and colluvium - QUATERNARY

Khu Upper tongue of Hilliard Shale

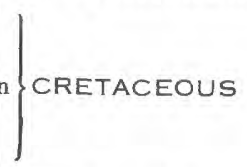

$\left.\begin{array}{ll}K b b & \text { Blind Bull Formation } \\ K h l & \begin{array}{l}\text { Lower tongue of } \\ \text { Hilliard Shale }\end{array}\end{array}\right\}$ CRETACEOUS

PPW Wells Formation - PERMIAN AND

$$
\text { PENNSYLVANIAN }
$$

PMa Amsden Formaticn - PENNSYLVANIAN AND MISSISSIPPIAN

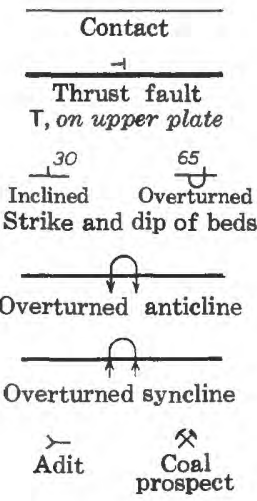

FIGURE 8. - Geologic map of the Blind Bull mine area in the northeastern part of the Afton quadrangle, showing location of type section (line with crossbars) of the Blind Bull Formation (heavy stipple) and of the lower and upper tongues (light stipple) of the Hilliard Shale. 
by J. B. Reeside, Jr. (written commun., Aug. 21, 1933) as follows:

USNM 15889

Inoceramus sp.

Ostrea sp.

Pholadomya cf. P. papyracea Meek and Hayden

Cardium curtum Meek

Legumen wyomingensis (Meek)

Mactra arenaria Meek

Niobrara fauna.

More than 1,300 feet of shale and siltstone of the upper tongue is preserved beneath the Darby fault on the east side of Mount McDougal in secs. 18,20 , and 29, T. 34 N., R. 115 W., where coaly beds in the upper 250 feet might be regarded as an upper part of the Blind Bull Formation rather than part of the Hilliard Shale tongue.

Mollusks, plants, and the tongues of the Hilliard Shale establish that the Blind Bull Formation is correlative with the Frontier Formation and the Hilliard Shale to the south and southeast and thus is of Late Cretaceous age. Whether beds as young as those in the lower part of the Adaville Formation are present in the Blind Bull anywhere in the region has not been determined. Tongues of Hilliard Shale have not been recognized in the Blind Bull Formation in the relatively poor exposures west of the Wyoming Range, where as much as 3,500 feet of post-Aspen beds (Rubey, 1958) is preserved beneath the Absaroka thrust fault (Rubey, 1973); thus, division into Frontier and Hilliard equivalents is impractical.

From these relations, therefore, the Shurtliff Sandstone Member of the Hilliard Shale may be regarded as a southward-extending tongue of the Blind Bull Formation.

\section{Type section of the Blind Bull Formation}

[Along the divide between Horse Creek and Hoback River, east of Deadman Mountain and 3 miles north of head of Blind Bull Creek, from the SW1/4 sec. 18, T. 35 N., R, 115 W., through the $S^{1 / 2}$ sec. 24 to the $S^{1 / 2}$ sec. 23, T. 35 N., R. 116 W. Measured by W. W. Rubey and J. Steele Williams, Aug. 25 and 26, 1931]

Wells Formation (part):

Thickness (feet)

83. Quartzite, light-gray, fine-grained, calcareous; weathers pale buff; regularly bedded; clear quartz grains

75

Darby thrust fault.

Hilliard Shale:

Upper tongue (part):

82. Siltstone and shale, poorly exposed

Blind Bull Formation:

Upper part:

81. Sand, uniformly light-gray, poorly exposed, soft, loose, calcareous, poorly sorted, coarse-, medium-, and fine-grained; many coarse grains; contains very light yellowish gray siltstone _..._._.

80. Sandstone, gray, calcareous; weathers brown shale beds 
Blind Bull Formation - Continued

Upper part - Continued

Thickness

(feet)

78. Sandstone, white to gray, massive. Near base a 3-in.-thick coaly bed. Fossil colln. AW191:

USNM 15886

Ostrea sp.

Cardium cf. C. curtum Meek

Tellina isonema Meek?

Mactra arenaria Meek

Baculites sp.

Halymenites major Lesquereux

Niobrara fauna (J. B. Reeside, Jr., written commun., Aug. 21, 1933)

77. Limestone, brown, sandy; alternating with sandy siltstone.

Limestone beds $2 \mathrm{ft}$ thick

76. Sandstone, light-gray, massive, soft; dark chert pebbles to $15 \mathrm{~mm}$ in diameter in lower part

75. Gradational sequence, in ascending order: black fossiliferous shale, nonfossiliferous black shale, coal pebbles and worn oyster shells, sandstone

74. Shale, gray

73. Shale, carbonaceous, highly fossiliferous. Fossil colln. AW190:

USNM 15885

Cardium pauperculum Meek

Corbula sp.

Colorado fauna (J. B. Reeside, Jr., written commun., Aug. 21, 1933)

72. Siltstone

71. Sandstone, fossiliferous. Fossil colln. AW189:

USNM 15884

Ostrea sp.

Modiola multilinigera Meek

Neritina, n. sp. aff. $N$. bellatula Meek

Colorado fauna (J. B. Reeside, Jr., written commun., Aug. 21, 1933)

70. Siltstone

69. Shale

68. Coal

67. Shale

66. Sandstone, regularly bedded; weathers yellow brown

65. Sandstone and siltstone. Sandstone soft (almost a loose sand), medium to coarse grained; abundant dark grains, very calcareous. Siltstone weathers light gray

64. Alternating sandstone, shale, and siltstone, poorly exposed. Sandstone is medium gray, weathers yellowish, greenish, and brownish gray, averages $2-3 \mathrm{ft}$ thick. Shale is dark gray, gritless, noncalcareous. Siltstone is gritty, greenish gray, weathers yellowish gray, noncalcareous

63. Sandstone and siltstone alternating with some coal. Upper $30 \mathrm{ft}$ poorly exposed and mostly sandy siltstone. Sandstone: massive to thin bedded, clay pellets, crossbedded, calcareous, yellow gray, weathers grayish yellow, beds lenticular and as much as $15 \mathrm{ft}$ 
Blind Bull Formation - Continued

Thickness

Upper part - Continued

(feet)

thick. Siltstone: calcareous, dark brown, weathers medium gray. Also some bluish-gray shale; weathers light gray. Sandstone, shale, and siltstone contain plant fragments. A coal bed, 17/10 ft thick, $42 \mathrm{ft}$ above base of unit. Bones in calcareous concretions in somber gritless shale. Fossil colln. AW138

62. Covered. At base is a blossom from a black carbonaceous shale or coal. Soil looks like that of carbonaceous clay rather than sandy shale except in upper $50 \mathrm{ft}$ where loose sandstone slabs cover surface

61. Sandstone and siltstone, alternating and poorly exposed coaly streaks. Sandstone white and thin bedded. Siltstone medium greenish gray, weathers light gray. Two 3 -in.-thick coal beds $4 \mathrm{ft}$ apart about $135 \mathrm{ft}$ above base

60. Covered. Sandy soil, has some medium-gray siltstone and soft white thin-bedded sandstone

59. Sandstone, light-buff, calcareous, hard; in beds $2 \mathrm{ft}$ thick; weathers gray and yellow. Poorly sorted, largest grains $3 / 4 \mathrm{~mm}$ in diameter. Numerous clay pellets, highly contorted beds in lower part. Sandstone beds alternate with beds of very light gray loose sand which in places are cemented into large loglike concretions. A 2in.-thick coal bed near top. Unit is well exposed and makes a prominent ridge

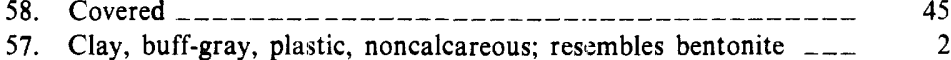

56. Coal, black, soft

55. Clay, brown, carbonaceous, gritty, noncalcareous

54. Poorly exposed except for thin sandstone slabs _...........-

53. Siltstone, sandstone, and shale; poorly exposed. Siltstone, sandy; sandstone, brown calcareous; shale, black carbonaceous 2 -ftthick layer near middle of unit. Abundant large pieces of petrified wood about $175 \mathrm{ft}$ above base

52. Covered except for a few thin-bedded gray friable sandstone ledges $2-5 \mathrm{ft}$ thick

51. Sandstone, light-gray to brown, thin-bedded to massive, some very calcareous, fine- to medium-grained (clear quartz, white opaque chert, black grains, and clay pellets). Beds $1-2 \frac{1}{2} \mathrm{ft}$ thick. Unit contains subordinate poorly exposed light-buff-gray sandy shale

50. Clay, brown carbonaceous; grades upward into yellowish-gray sandy shale

49. Coal

48. Clay, medium-dark-brown, gritty; weathers very light gray

47. Coal

46. Shale, gray, gritless, platy

45. Coal

44. Clay, black carbonaceous

43. Sandstone, light-yellowish-gray

42. Covered

41. Sandstone, calcareous, medium-grained (clear quartz, opaque white chert, black grains, and clay pellets), s sbrounded to angular. Regularly bedded in beds $1-6$ in. thick 
Blind Bull Formation - Continued

Upper part - Continued

Thickness

(feet)

40. Siltstone, medium-brownish-gray noncalcareous gritty; weathers light buff gray. Thin coaly layers. Yellowish-gray sandy limestone beds $1 / 2-1 \frac{1}{2} \mathrm{ft}$ thick; some have contorted bedding --

39. Sandstone, yellowish-gray, calcareous, heavily iron-stained, medium-grained; weathers grayish yellow. Irregular ripple marks

38. Shale, sandy; several sandstone beds $1 \frac{1 / 2-5}{\text { in. thick }}$

37. Coal; mostly glance; units 35 and 37 are the coal mined at the Blind Bull and Vail mines

36. Clay; brown parting

35. Coal; mostly glance

34. Claystone, gray; like unit 30

33. Coal, bony

32. Claystone and shale with ironstone masses and harder irregular oolitic ironstone concretions

31. Coal, impure

30. Claystone, gray, somewhat gritty

29. Siderite; nodular concretionary masses, septarian

28. Sandstone and shale; a few beds of coal less than $2 \mathrm{ft}$ thick. Sandstone greenish gray, salt and pepper grains at base. Irregular bedding and current marks. Yellowish-brown sandy limestone at top

27. Sandstone, greenish-gray to yellowish-gray, hard. Salt and pepper grains as much as $1 / 2 \mathrm{~mm}$ in diameter, average $1 / 8 \mathrm{~mm}$. Much crossbedding (from south and from northwest). Bed near top has abundant clay pellets which weather out, leaving conspicuous holes

26. Sandstone, hard, massive, regularly bedded; forms ridge; alternates with subordinate sandy shale and dark-gray clay. Sandstone beds are mostly 4-10 ft thick, but a few are thin. At top of unit sandstone is irregularly bedded and ripple marked. Conspicuous black grains. Fossil colln. AW166 from near base of unit:

USNM 15881

Barbatia micronema Meek

Inoceramus cf. I. deformis Meek

Ostrea [Crassostrea] soleniscus Meek

Ostrea [Crassostrea] of. $O$. coalvillensis

Meek

Anomia propatoris White

Cardium curtum Meek

Tellina isonema Meek?

Mactra arenaria Meek

Gyrodes cf. G. depressa Meek

Gastropods, undet.

Early Niobrara age (J. B. Reeside, Jr., written commun., Aug. 21, 1933). Fossil colln. AW 187 (Inoceramus, baculite, and plant fragments) from just below middle of unit

25. Shale and sandstone, alternating; both calcareous. Sandstone beds as much as $1 \frac{1}{2} \mathrm{ft}$ thick, most less than 4 in _...

24. Sandstone and sandy siltstone, calcareous, gray to blue-gray; sandstone beds $3-8$ in. thick 
Blind Bull Formation - Continued

23. Sandstone and siltstone, sandy. Sandstone is soft, thin bedded, light yellowish gray. Oscillation ripple marks $1 \frac{1 / 2}{2}$ in. wide, $1 / 4$ in. deep, trend N. $30^{\circ} \mathrm{W}$.

22. Poorly exposed. Yellowish-gray sandy soil; abundant slabs of brown sandstone on surface

Total upper part of Blind Bull

Hilliard Shale: Formation

Lower tongue:

21. Shale, dark-brownish-gray, fissile, slightly gritty, calcareous, wellexposed; a few thin calcareous sandstone beds

20. Shale, dark-brownish-gray, slightly gritty, calcareous; weathers medium dark gray; poorly exposed

19. Poorly exposed. A few thin beds of sandstone, pale buff gray, nonfossiliferous

18. Sandstone, highly calcareous, fetid odor, highly fossiliferous. Fossil colln. AW186:

USNM 15883

Barbatia micronema Meek

Inoceramus cf. I. gilberti White

Ostrea [Crassostrea] soleniscus Meek

Modiola multilinigera Meek

Cardium cf. C. pauperculum Meek

Volutoderma cf. V. plicatula Dall

Niobrara fauna (J. B. Reeside, Jr., written commun., Aug. 21, 1933)

17. Sandstone, medium- to light-gray, highly calcareous; weathers brown; fetid odor. Grains subrounded, average $1 / 3 \mathrm{~mm}$, many dark minerals. Highly fossiliferous at base and at three calcareous zones above. Fossil colln. AW185:

USNM 15882

Inoceramus deformis Meek

Ostrea congesta Conrad

Pseudomelania? sp.

Gyrodes sp.

Turritella? sp.

Volutoderma plicatula Dall

Lower Niobrara fauna (J. B. Reeside, Jr., written commun., Aug. 21, 1933)

16. Poorly exposed; a few layers of thin-bedded fine-grained calcareous sandstone exposed. Fossil colln. AW184 (plant fragments) -_-

15. Siltstone, medium-gray, sandy, platy, calcareous. Fragments of fossiliferous sandstone (pelecypods)

Total lower tongue of Hilliard Shale

Total upper and lower tongues of

Hilliard Shale

Blind Bull Formation:

Lower part:

14. Largely covered but has some exposures of hard calcareous siltstone and sandstone like those in unit 13 
Blind Bull Formation - Continued

Lower part - Continued

Thickness

(feet)

13. Siltstone, medium-greenish-gray, soft, calcareous; weathers light yellow gray. Includes numerous 2-ft-thick ledges of harder siltstone and fine- to medium-grained sandstone. Near top are brownish-gray calcareous concretions

12. Siltstone, medium-gray; weathers light buff gray. Includes a few 6in.-thick beds of very ferruginous sandstone and siderite

11. Soil, light-yellow, sandy, poorly exposed

10. Siltstone, yellow-weathering, sandy, poorly exposed; nodular masses of ferruginous sandstone

9. Siltstone, medium-gray, very calcareous; weathers brownish to greenish gray

8. Siltstone, gray; hard 7-in.-thick bed of greenish-gray porcelanite with biotite flakes

7. Limestone, medium-buff-gray, hard, silty; weathers dark to light brown

6. Covered. Probably carbonaceous shale

5. Siltstone and subordinate shale. Siltstone is sandy, medium brownish gray; weathers buff gray. Petrified wood abundant. Fossil colln. AW 165. Black gritless highly calcareous siltstone in beds 2 $\mathrm{ft}$ thick at several levels. Hard concretionary dark-brown silty limestone near middle. Black carbonaceous shale about $4 \mathrm{ft}$ thick at top

4. Siltstone, sandy; chiefly gray but includes gray to brown friable poorly sorted sandstone. All highly calcareous. Sand grains average $2 / 3 \mathrm{~mm}$ in diameter but are as much as $11 / 2 \mathrm{~mm}$. Chiefly quartz but also white opaque chert, dark minerals, and pale-green grains

3. Alternating silty sandstone and sandy siltstone, brown to greenishgray. Grains as much as $1 / 2 \mathrm{~mm}$ in diameter, angular, many dark grains. Beds are very soft and friable. A dark-gray gritless noncalcareous clay with a thin bony coal 8 in. thick about $3 \mathrm{ft}$ below top of unit

2. Siltstone, soft, sandy, poorly exposed

Total lower part of Blind Bull Formation

Total upper and lower parts of Blind Bull

Formation

Total of Blind Bull Formation and two

Hilliard Shale tongues measured

Aspen Shale (part):

1. Porcelanite beds, hard, medium-bluish-gray to black. Some soft blue-gray shale and a few 6- to 8-in. thick beds of sandstone

\section{REFERENCES CITED}

Andrews, D. A., 1944, Preliminary geologic and structure maps and coal sections, Willow Creek coal area, Lincoln County, Wyoming: U.S. Geol. Survey map with text and sections. 
Brown, R. W., 1936, Field identification of the fossil ferns called Tempskya: Washington Acad. Sci. Jour., v. 26, no. 2, p. 45-52.

Cobban, W. A., and Reeside, J. B., Jr., 1951, Lower Cretaceous ammonites in Colorado, Wyoming, and Montana: Am. Assoc. Petroleum Geologists Bull., v. 35, no. 8, p. $1892-1893$.

1952, Frontier formation, Wyoming and adjacent areas: Am. Assoc. Petroleum Geologists Bull., v. 36, no. 10, p. 1913-1961.

Eyer, J. A., 1969, Gannett Group of western Wyoming and southeastern Idaho: Am. Assoc. Petroleum Geologists Bull., v. 53, no. 7, p. 1368-1:390.

Frerichs, W. E., and Steidtmann, J. R., 1971, Sea level variations during deposition of the Hilliard Formation (Upper Cretaceous), western Wyoming, in Symposium on Wyoming tectonics and their economic significance, Wyoming Geol. Assoc. Guidebook 23d Field Conf., 1971: p. 157-168.

Furer, L. C., 1970, Petrology and stratigraphy of nonmarine Upper Jurassic-Lower Cretaceous rocks of western Wyoming and southeas :ern Idaho: Am. Assoc. Petroleum Geologists Bull., v. 54, no. 12, p. 2282-2302.

Mansfield, G. R., 1927, Geography, geology, and mineral resources of part of southeastern Idaho, with Descriptions of Carboniferous and Triassic fossils, by G. H. Girty: U.S. Geol. Survey Prof. Paper 152, 453 p.

Mansfield, G. R., and Roundy, P. V., 1916, Revision of the Beckwith and Bear River formations of southeastern Idaho: U.S. Geol. Survey Frof. Paper 98-G, p. 75-84.

Moritz, C. A., 1953, Summary of the Cretaceous stratigraphy of southeastern Idaho and western Wyoming, in Intermountain Assoc. Petroleum Geologists 4th Ann. Field Conf., 1953: p. 63-72.

Read, C. B., and Brown, R. W., 1937, American Cretaceous ferns of the genus Tempskya: U.S. Geol. Survey Prof. Paper 186-F, p. 105-129.

Ross, A. R., and St. John, J. W., 1960, Geology of the northern Wyoming Range, Wyoming, in Overthrust belt of southwestern Wyoming and adjacent areas, Wyoming Geol. Assoc. Guidebook 15th Ann. Field Conf., 1960: p. 44-56.

Rubey, W. W., 1958, Geology of the Bedford quadrangle, Wyoming: U.S. Geol. Survey Geol. Quad. Map GQ-109.

1973, Geologic map and structure sections of the Afton quadrangle and part of the Big Piney quadrangle, Lincoln and Sublette Counties, Wyoming: U.S. Geol. Survey Misc. Geol. Inv. Map I-686, 2 sheets.

Schultz, A. R., 1914, Geology and geography of a portion of Lincoln County, Wyoming: U.S. Geol. Survey Bull. 543, 141 p.

Smith, J. H., 1965, A summary of stratigraphy and paleortology, Upper Colorado and Montanan Groups, south-central Wyoming, northeastern Utah, and northwestern Colorado, in Sedimentation of Late Cretaceous and Tertiary outcrops, Rock Springs uplift, Wyoming Geol. Assoc. Guidebook 19th Ann. Field Conf., 1965: p. 13-26.

Veatch, A. C., 1907, Geography and geology of a portion of southwestern Wyoming: U.S. Geol. Survey Prof. Paper 56, $178 \mathrm{p}$.

Yen, Teng-Chien, 1951, An Upper Cretaceous nonmarine molluscan fauna from the Leeds Creek area, Lincoln County, Wyoming, pt. 2 of Fresh-water mollusks of Cretaceous age from Montana and Wyoming: U.S. Geol. Survey Prof. Paper 233-A, p. 11-18.

1952, Freshwater molluscan fauna from an Upper Cretaceous porcellanite near Sage Junction, Wyoming: Am. Jour. Sci., v. 250, no. 5, p. 344-359.

1954, A fauna from western Wyoming, pt. 1 of Nonmarine mollusks of Late Cretaceous age from Wyoming, Utah, and Colorado; U.S. Geol. Survey Prof. Paper 254-B, p. $45-59$. 



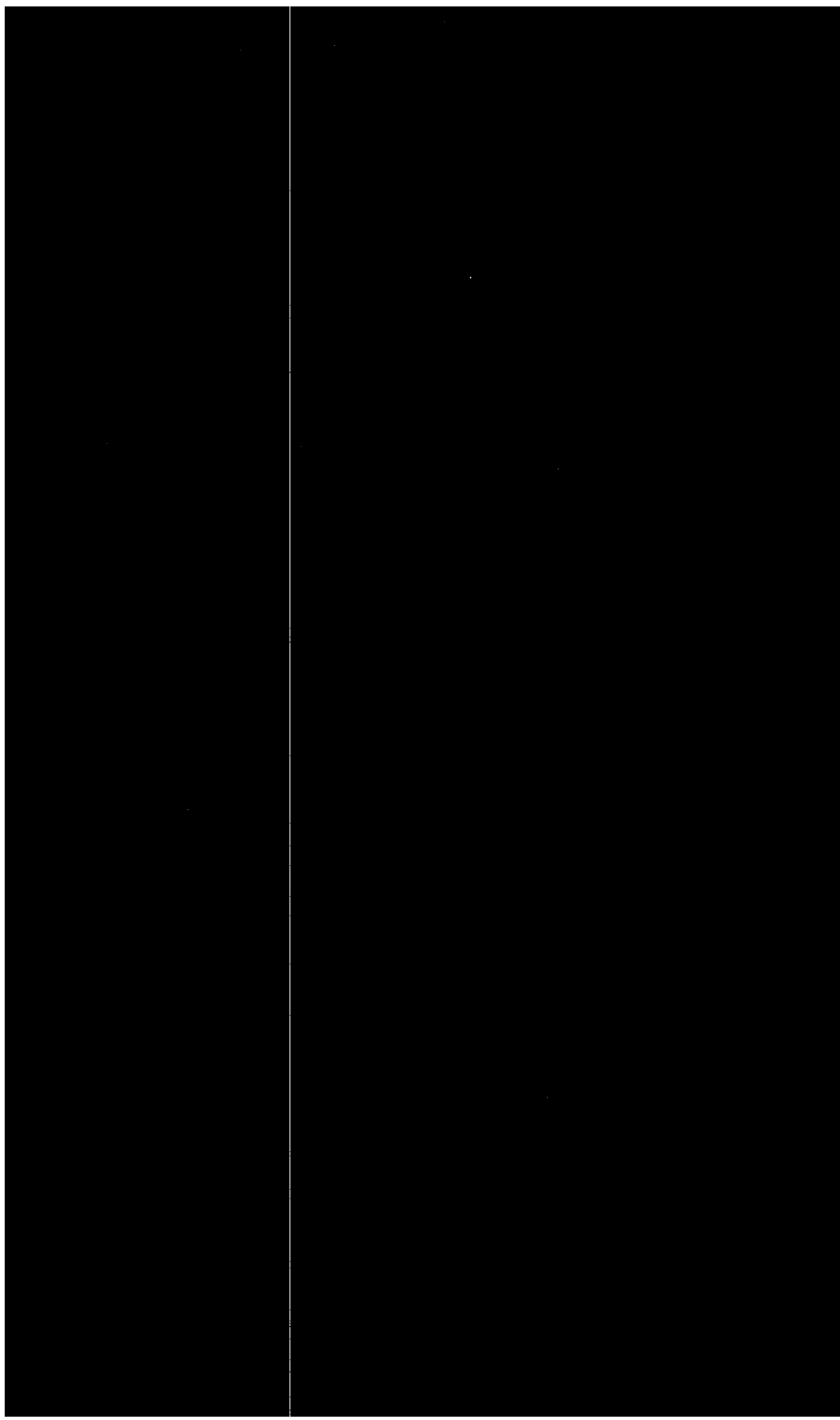




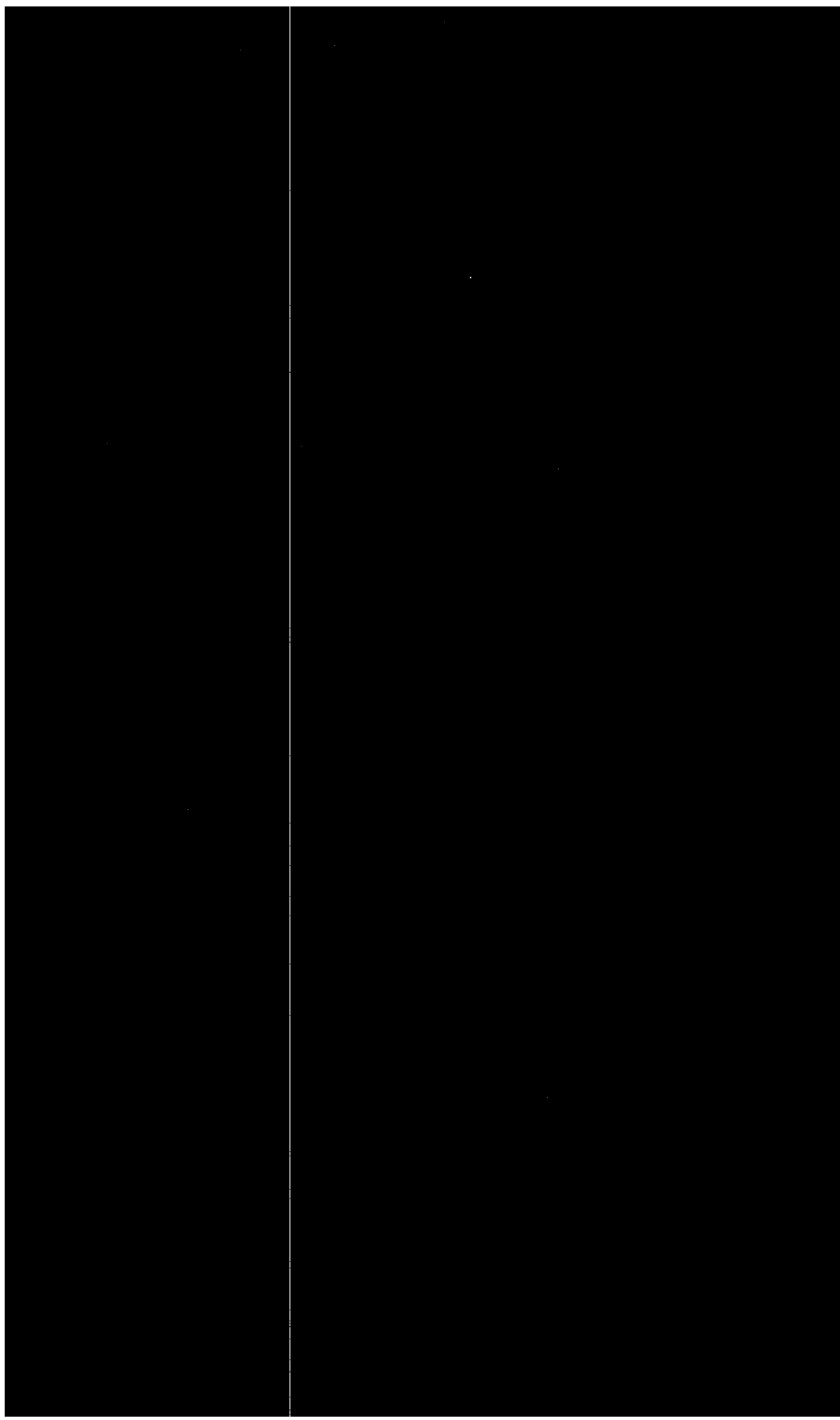

